University of Louisville

ThinkIR: The University of Louisville's Institutional Repository

Electronic Theses and Dissertations

1934

\title{
A study of manuals for teachers.
}

Alice Corwin

University of Louisville

Follow this and additional works at: https://ir.library.louisville.edu/etd

Part of the Educational Methods Commons

\section{Recommended Citation}

Corwin, Alice, "A study of manuals for teachers." (1934). Electronic Theses and Dissertations. Paper 1693. https://doi.org/10.18297/etd/1693

This Master's Thesis is brought to you for free and open access by ThinkIR: The University of Louisville's Institutional Repository. It has been accepted for inclusion in Electronic Theses and Dissertations by an authorized administrator of ThinkIR: The University of Louisville's Institutional Repository. This title appears here courtesy of the author, who has retained all other copyrights. For more information, please contact thinkir@louisville.edu. 
UNIVERSITY OF LOUISVILEE

A STUDY OF MANUALS FOR TEACHERS

\author{
A DISSERTATION \\ SUBMITTED TO THE FACULTY \\ OF THE GRADUATE SCHOOL OF THE UNIVERSITY OF LOUISVILLE \\ IN PARTIAL FULFILLMENT OF THE \\ REQUIREMSNTS FOR THE DEGREE OF \\ MASTER OF ARTS
}

DEPARTMENT OF EDUCATION

B

$\mathrm{Y}$

A L I C E C O R I I N

19934 
AEMUODIEDGELENTS

\begin{abstract}
Aeknowledgament is dise to Dr. J. J. Oppenhetear,
Departwant of Gdueation, Unirersity of Louierille, for guidance in the preparation of thle thesis.

Dr. Kaywiond A. Kent, president of the Univeraity of Louivilio, and Dr. Idward Blom, Assiotent superintendent in Cherge of Research of the Lolisvil2. Public Schools, and Las Hilin ilhrozkeld, Dekn of Wowen of the lniversity of

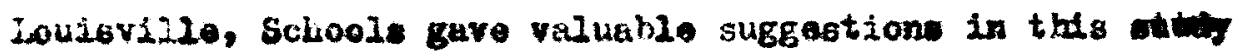
for whioh the writer is oinoerely grateful.
\end{abstract}


TABLE OF GONTHVIS

List of Bables

Page

Trble I-n...."Rules and Regulations" Studied-......... 22

Table II---Toples Ineluded in lemualg-n............. 25

Introduetion--The Study-Purposes, Nature, end

Justifleation-........................ I

Chapter I-----Suanary of Other Investigations Upon the Problew- 6

Chapter II-.-Anelysea of Representative Henualg--.-- 15

Chapter III---The Board of Eduation"s Polteies to-

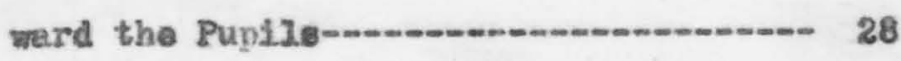

Chapter xy-n-The Boerd of Edueetion's Attitude to-

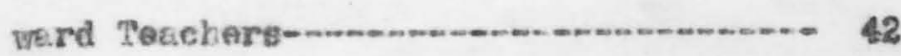

Cheptor V-w.-The Boerd of Educetion'B Relations with the Publie-nom 52

Chapter VI-.-.-Menuel for Teechers (based upou the minutes of e. Besrd of Zducation) -........ 58

Chapter Vzi-.-Conclusions Dram from the study-n..... 100

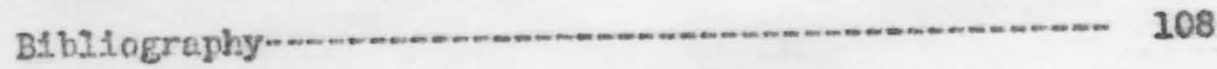

Appondix-a.n- Gheck list to Deternine Gontent of Mentue: 


\section{A STUDY OF MANUALS FOR TBACHISRS}

\section{INTRODUCTION}

Purposes of the Study

This study of manuals for teachers was undertaken for the purposes (I) of determining the practices of boarde of oducation as they are reflected in handbooks, in order to learn how far they conform with modern educational philosophy and good administrative practices; (2) and of discovering just what waterial should bo embodied in a booklet of rules and regulations for teachers of a city school system and writIng such a manual based chiefly upon the minutes of a board of education.

\section{The Nature of the Study}

The investigation was essentially an analysis and evaluation of current handbooks for teachers and a careful study of the minutes recorded during the past twenty years by a board of education.

The waterials used were the following

1. Manuals frow eighteen school systems.

2. The records of the Secretary of the Board of Bducation.

3. A check list of iteme presented to representative principals and teachers.

The teahniques employed were as follows:

1. A study of the literature on the subject.

2. The formulation and use of a check list.

3. Interviews with representative educators in order to find 
out what the teachers wanted to know in regard to their school system and its policies.

\section{Justifleation of the Study}

The important role of a manual can hardly be questioned. If carefully prepared, it may play a large part in creating that kind of atmosphere in which all the board of education omployees work together more happliy, enthusiastically, and harmoniously than they otherwise would. The handbook seeks to adjust the teacher readily to the material resources of the syotem and to the extracurricular and routine business 1 ife of the school.

It has certbin advantages that can be secured by no other means. It serves as a ready reference and guide, easily available when needed. Printed matter can be taken home by the teacher and studied at leisure. Oral directions and suggestions are soon forgotten or confuged and so result in ambarrasgent and in serious 108 of efficiency. Often a letter reminding teachers of a duty or a policy is sent out by the sdministrator's office as a result of some teacher's misteke, which a wise use of a manual aight have avoided.

A little research into the provalence of handbooks reveals they have been prepared for every class of workers - all the way from army bakers to United States' imaigrants. They have appeared in practically all flelds where there is a demand for information, because they provide a method whereby information

1 "Handbook" and "Manual" are used synonywously to refer to a booklet of policies, principles, or rules and regulations. 
may bo organized and disseminated; consequently, they are a cone venient weans by which teachers may understand the principles and polieies of the administrators.

Teachers when cognisant of the philosophy of the board of education are much more intelligent workers. "As is the teachers, so is the school" has becone an educational maxim. The persona1ity, vision, and skill of elassroom teschers are powerful factors in the school organixation, for they condition educational progress. Any means or agency that makes for better vision, greater enthusiass, and a clearer understanding in the teaching corps contributes abundantly to the realisation of the onds for which the school exists.

Rules are necessary for the proper maintenance of any school system. Too many detailed regulations are impractical, but the absence of a.11 written rules for guidance is oven wore unwise. The necessary rules and regulations formulated by the administrators give to a school aystem both unity and stability - important factors in any organization.

A handbook of regulations enables each teacher to know his own functions, and it definitely places responsibility. Friction, which reduces the work of the board of education just as it does the movenent of a machine, is lessened; while the prace tice of blaning some one else in the system - a pastine usualy called "passing the buck" - is checked. The availability of these rules and regulations established traditions and habits which make for prompt action and result in a degree of coordination of activities, otherwise impossible. 
Such rules are eapecially helpful to nev teachers and to those who have recently ontered the organisation from other Comanities. They imediately inform such orployees of their power and duties and prevent their groping in the dark. Moreover they facilitate the training of inexperienced workers, for, when preeented to boginning employees, these written instructions result in greater satiafection to the teachers and in loss loss to the school system itself. If thoughtfully prem pared and humanely enforced, they create a desírable atmosphere and frequentiy provent misunderstandings.

Capable followers must have an intelligent appreciation of the purposes, plans, and programs advocated by the leaders. A handbook may become one of the factors tending to sake teachIng both an art and acienee, if that handbook rather clearly reflects the philosophy supported by the board of education and policies which aro outgrowths of that philosophy.

Nanuals are often useful also in comparative studies. They furnish a cenvenient means whereby one city may learn the procedure of other school systeme.

\section{Sources of the Date}

1. Manual fron various school systems were snalysed. Three of these nesuals came frow Nev Ingland cities, three from the Middlo Atlantic section, eight from the Central, three from the Southern, and one from the Western. Three were issued by states, bot citios, but their recent date and the fact that city manuals must not conflict with any state hendbooks made then valuablo in the study. 
2. The minutes of a board of education supplied the polieies that determine the rulings of that particular board.

3. Educational 11terature furnished the ideals of achool administration and pilosophy as supported by authorities.

4. Interviews with teachers gave material that teachers need in handbook.

\section{Yothods Used}

From the sources used and the type of the problew, it followed that the methoda used were chiefly descriptive and analytical, although syuthosis was employed in the construction of the manual.

\section{Procedure}

1. Previous studies in the sield were reviewed.

2. Accoptablo eduestional philosophy and administration were discovered frow the writings of authorities upon the subject.

3. All the available manuals for teachers were analysed.

4. Teuchers were interviowed in regard to the subject matter they deaired in a handbook.

5. The minutes of a board of education were read.

6. Policies and rulings for teachers were formulated from the minutes read. 


\section{CHAPTSR I}

SULMARY OF OTHER INVESTIGATIONS UPON THE PROBLEM

Nany administrators have atudied the content and have investigated the usefulness of manuals for school people.

As early as $1920 \mathrm{~J}$. Boggs published the results of his study in an article ontitled "School Board Regulations Concern1

Ing the Elementary School Principal".

He found that many citios were completly revising their rules and supplementing thew with bulletins, handbooks, otc. Ho decided, fros a study of the rules of thirty cities, that the weaknesses of the regulations were due the following characterist1es:

1. Inconsistent with present day theory.

2. Too detailed on points which should be discretionary.

3. So vague as to be meaningless.

4. Not coordiented with state rules and laws. Bven before that time william $W$. Theisen ${ }^{2}$ made an investigetion based on study of the school board rules in a hundred citiss. He discovered that the first publications considered the school board and superintendent; then handbooks for principals were provided; and later those for teachers were deemed adviable.

1 "School Board Regulations Concerning the Elementary School Principal", The Elementary Sc. Journal, Vol. XX, No. 10, June, 1920, p. 730-742.

2 The City Superintendent and the Board of Education, Contributions to Education, No. 84, Teachers College, Colunbia Univ., Nev York City, 1917, p. 12\%-32. 
The Seventh Yearbook, the Bulletin of the Department of Blewentary School Principals, The Elementary School Principalghip, 1 sists the duties prescribed for elementary principals in 25 cities of over 100,000 population. "Make sure that the teachers are aequainted with the Board rules" is one of the duties wertioned; obvioully these eities had rules for teachers.

In an article, entitlad "A Critical Analysis of Rules and Regulations", B. 0. Melby $^{3}$ published his findings after a strdy of manuals. He canvassed $416 \mathrm{eity}$ school systems, including all cities having a population of 20,000 and more, or, omploying wore than 100 teachers. Three hundred thirty-nine replies were received with 141 sets of rules and regulations which were in operation during 1925-26. Of these, 111 were printed in separate bookleta; while the others were nimeographed or incorporated in the annual regort or other publications. The average number of printed pages in these boollets was 33. In another article, "A Check List for the Preparation of Rules, Regulations, and Fritten Instructions", Melby diacussed the guiding principles for rules and segulationa and presenta a detailed check list. He suggeato that the techaiques developed by industry in job analysis might be helpiul. He eaphasized the necessity for constant study and revision in order that the written rules way harmonize with ehangIng practices. School Board Journal, No. 72, Narch 1907. American School Board Journal, No. 74, May, 1927, p 43-45. 
F. N. Anderson ${ }^{5}$ studies manuals for school officers and pointed out the advantages of carefully worked-out rules and regulations and formlated a suggested list of rules for teachers and prineipels. He gtresses the necessury perquisites of good judgent and a horough understanding of the problems Involved before the making of regulations is attempted.

N. L. Enghelhardt and Fred Engelhardt in their work, Public School Business Administbation 6 , present guiding principlos for the preparation of rules: outline aejor topics to be covereds quote Melby ${ }^{\circ}$ Checking list for rules; and give suggestions for preparing writton iastructions. They diatinguiah between (a) rules which deal with authority, reaponsibility, and relationehips, and (b) written instructions, which are administrative devices.

A. L. Heer in en article, entitled "A Neglected Principle of Organiation in the Administration of our Public Sehools", discusses the need for definiteness in assigning duties in school organization and deplores the fact that only 83 of 206 cities above 25,000 in population owned printed rules and regulatione In $192 \%$.

Rdgar Mendenhal1 8 , in a study of the eity school board 's takk, gives reasons for school rules and suggests the characteristics of a good set of rules. He finds that regulations do not

5 Anderson, W. N., A Manuel for School officers, The Contury Co., New York, 1925, Chapter 9, "Rules and Rogulations," p 134-151.

6 Engelhardt, N. Lo and Engelhardt, Fred, Public School Business Adainigtration, Bureau of Publications, Teachers College, Columbia University, New York City, 1927, p 150-162. Heer, A. L., "A Neglected Principal of Orgenization of our Public Schools", Bducational Researeh Bullotin 6, March, 1927, p 101-4. College Inn Book Store, PIttsburg, Kanse.s, 1929, D 31-32. 
check iaitiative, and ho thinks that rulss should be definitely stated in order to avoid miaundergtandings and should be detalled enough to define duties and to place responsibility.

J. C. Morrison ${ }^{9}$, in an articlo upon the subject, reports his study of school board rules in twenty IIInois cities. He gives the frequency of appearance of certein topics, and, in answer to the criticisw that rules and regulations are too inPlexible, suggests that they be printed in loose leaf form, ao that revision can be entered convenientiy. In his principles of guidence in the preparation of rules he gives the following ones:

"1. Rules and regulations should be formulated from an analysis of the service to be rendered.

2. Rules and regulations should definitely fix responsibility.

3. Rules and rogulations should elininate the overlepping of authority.

4. Rules and regulations should grow out of the experience of the men and women parforming the service, subject to the approval of the representatives of the people who are to be sarved.

5. Rules and regulatione should be constantly subject to rovision under such conditions as would insure the conaideration for the public good".

Mr. Morrison adds, "When one examines rules and regulations now in force, one is not aurprised that some superintendents $200 k$ upon them 28 being "too mechanical" or "too Plexible". When Regulations Covering the Work of the School Board and the Superintendent", American School Board Journal, No. 73, Fobruary, 1926, p 48-50. 
they deal with petty detall rathor than broad administrative principles when they have been made by the scissors and paste method rather than from a thorough knowledge of the service rendered...they are...to be condemned". However, he feelo that regulations properly formulated way be oxceedingly helpful.

w. G. Reeder in his work, The Business Administration of E School System, 10 , lists the chief standarda which the rules of a school organisation should weet. He phasizes the point that rules and regulations should state in unequivocal languege the functions of the various employees. He insists that they should not be so rigid as to make it impossible for workers to exprese their individuelity, when to do so would result in greater efficiency. The importance of amending archaic and useless rulos and of following exiating ones is also stressed.

The Department of Superintendence and Research Division of the National Bducation Association received so meny requests for the wames of cities that had recentiy published rules that in 1929 that department collected copies of the rules a d regulations governing schools of over 30,000 in population. 95 eitios furmished copies of rules, 36 replied that they were revising theirs at that tima. A cirular 11 published as a result of the study of those 95 handbooks, shows that an examinetion of the format and content of the manuals revealed, in regard to the characteristice of a wellorganized set of rules and regulations, the facts which are gumarizod in the paragraphs that follow. tene, Gina \& Co.. Boston, 1929, p. 227-232, 276-282, 389-402. 
In 83 of the cities the by-laws, rules, and regulations are published separately; while in 10, they are printed in annual roports, directories, or handbooks. A few cities have handbooks in addition to their regular publications of rules and regulations. In 1931 George D. Talbot ${ }^{12}$, who made an intensive study of fifteen handbooks, found that there was littlo similarity in their content. The question at ohee arose as to the reason of the disaimilarity. Was it due toe the diffenent enviornments served, or were the handbooks providing needed information or just information? In order to find out $M r$. Talbot presented a check list of 170 Items to 302 teachers, who were asked to check all items which thoy felt should be discussed in a handbook for their aystem, if such a book were to be of maximum value. Provision was made for the writing in of essential items not mentioned in the check list. The responses showed that teachers, wherever located, need practically the same information, and the variations in subject matter that did occur were due to the differences in the size of the school aystes. Mr. Talbot concluded that in many cases the handbook may prove an efficient means of putting information Into the hands of the teachers, and that his check 1ist, accepted by the 302 teachers, might provide an objective basie for the organisation of new handbooks.

The authorities agree that the major requisites of manuals Include the following:

1. They should contain guiding principles as well as detailed rules. 
2. They should be consistent with existing school laws and with actual school practice.

3. They should elearly set forth lines of authority and other relationahips.

4. They should be sufficiently detailed to allocate duties and to $\mathrm{Pix}$ responsibility without destroying initiative.

There is a wide difference in the size of the books; the variation extending from $3^{\mathrm{m}} \times 5$ / mimeographed eheets. Thirty-three systems use the $6^{\prime \prime} \times 9^{\prime \prime}$ gire, while that many others use pocket size editions mearuring $4^{n} \times 6^{\text {" }}$ or $3^{* n} \times 6^{n}$.

The largest manual is Boston's 367 page velume. Only 12 have wore than 100 pages, and 29 have 25 or fewer pages. The number of pages is not always a measure of the amount of reading matter be cause there is a wide variation in the sixe of the type used. A fow manuals employ type too small to be readable. 10-point seesis to make the wost legible balklet.

Most of the specific rules or regulations are numbered. More than half have a complete numbering of main divisions and aubdiviglous which makes for convenience in finding a spociflc itom. In the paragraphy are numbered coneecutively throughouts 14 have independent aections which are not numbered but which have numbered sub-headings .

About a third are without index or a table of contents; while not quite that proportion contain both. The others have one of the twod When both are supplied, the book is much more usuable. Five are undated. 82 percent of the others bear a date of publication later than 1924. 
Thirteen include provision for belng kept up-to-date. Three are in loose leaf form. The others include blank pages for changes. There is a wide variation of titles, including Rules and Regulations, By-lews and Rules, Administrative Code, Manuel, and Handbook.

All of the booklets mention the following items: (I) board of education, (2) secretary to the board, (3) treasurer to the board, (4) attorney to the board, (5) superintendent of school, (6) assis= tant or associate superintendents, (7) business maneger, (8) superintendent of buildings, and grounds, (9) supervisors, (10) directors, (11) director of research, (12) heads of departments (13) attendance officers, (14) elerks, (15) principals, (16) assistant principals, (17) taachers, (18) substitute teachers, (19) pupils, (20) superintendent of engineers and janitors, (21) ongineers and janitors, (22) director of heelth, (23) physicians and medical inspector, (24) nurses, (25) dentists, (28) hoalth and medical regulations, (27) school calendar, (28) community use of buildings, and (29) interschool relationships.

Combining that seen to be the best of desirable characterigtics listed by Mendenhal1, Lorrison, and Reeder, the following group should form a reliable criteria for manuals:

I. Content

A. Rules should be in harmony with present day theory and existing school laws.

B. They should be guiding principles rather than detailed instructions. Potty details should be omitted.

6. They should very definitely fix responeibility and define duties whout killing initiative and individuality. 
D. They should be clear as to meaning. Vague and general rules are ineffective. They should be clearly stated; go misunderstendings as to thejr meanings vill not ariee.

I. They should be reduced to writing, for, when crystallised in written language, they project themselves into reality and are less apt to be forgotten both by those who make then and by those for whose guidance they are made.

5. They should be constantly subject to revision. A rulo that is no longer needed should be repealed and not bo allowed to become a dead letter. New rules should be adopted to keep pace with the growing school syotem and the changing times.

G. They should be simple, elear, and just.

H. They should be developed on the assumption that profossional attitudes toward work will be the guides of all the workers in the system.

2. Form

A. They should be woll organized under proper heads and sections.

B. They should contain a table of contents.

C. They should have readable type.

D. They should be of a convenient size.

E. They should have space for changes and additions. 
GHAPTER II

\section{ANALYSES OF RWPRESLNTATIVE MANUALS}

All the anuals that could bo securad from various school syotems were analyzed in detail. The maauls studied were obtained In response to letters written to the city superintendents of schools. Many did not replys some wrote that they had no manual; while still othors said theirs was being revised. One book sold for one dollar thirty cents. Two superintendents asked that theirs be returned. Although but eighteen vere received, these represent eities of various aize in gixteen different states from every section of the Union. Such a schence sampling ought to be representative.

Three state menuals, which in addition to the others, were received have wore relation to the subject than the casual observer would realise. City handbooks must be consistent with those 1ssued by the state, and the two possess wany elements in conmon. The state manuals of Kentucky and of Indiana are of recent date and more nearly approach the eriteria established by authorities than do some of the others.

A study of representative manuals brings out the fact that the rules and regulations of a eity board of education embody to a considerable degree the policies of those in charge of the schools. They also reveal wuch that is current in educationel proactice. They ahow that twenty-eight percent of the boards of education represented by manuals indicate that it is the function of the school to guide the $\mathrm{R}$ upil'g instinct for self-expression; to prom vide for freedon of individual response, and to supply comunity11 fo atimuli and guidence. 
In one handbook ${ }^{2}$ the ideas are expressed thus: "Activities based on life situations should be selocted in accordance with the Interesta, needs, and abilities of individual pupils", and one of the purposes of the school is given in the following words, "To develog a sirit of good will, friendliness, and understanding on the part of every individual toward his fellow belngs in his own comerunity, in his nation, and in other nations".

From the regulations that apply speciflcally to teechers and pupils, it can be seen that out of 18 of the boards of education studied, 10 teke $\operatorname{cognisanee}$ of the facts that education is through purposive activity, that evarything that boys and girlo do with aөs is educative, provided the cetivities have leading-oh qualities, and that the aim of oducation is continuous growth, physical, mental, omotionel and social. To quote the Administrative Handbook for Indiana Schools, "the development of attitudes is the wost lesting of all the oxporlenees that one res11zes in sehool and the most potent in shaping one ${ }^{\circ}$ s future career and activity". The Manual of Organization and Administration for High Schools of Kentucky says that the school should meke an enrnest endeavor to explore the pupile" abilities, likes, and disilkes.

In the sections devoted partienlary to teachers - their duties, rating, and salary schedules, it is seen that takchers are expected to be students of educational problems, and that they are to make reasonable effort to improve thenselves in their profession, although professional preparation above the winimum requirement

1 Directory and By-Laws of the Bosrd of Bducation of Dotroit, Mich., 90. 
has no value to the school unless it results in better service in the system. ${ }^{2}$ It way also be deduced that boards of education believe that, when hagh professional 1deals are held, and when the worker is imbued with an ambition and a professionel pride to reach these ideals, thes the best, the wost exacting, and the zost helpful supervialon is self-supervision. The best service is not that which is demended at the point of rules and regulations, but is that which is given freely by the employee who assumes warginal duties and goes the second ale in performing his obligetions ${ }^{3}$. One does not have to read far between the IInes to PInd that the establighuent of happy, helpful relations between the teacher and the learner, as well as betwean the administrator and the tescher, is the suprene test of any school system.

The better handbooks do not try to go very far into detadl but rather outline the policles and principles of the board of education and the superintendent. Their rulas are not too rigid and mechanical, but are based on good common sense and an understanding of human nature. A careful examination of the manuals ahows that there is wide variation in their content. Note anajysis of handbooks $\mathrm{p}$. Many of the books contein salary schedules and articles upon the efficiency and reting of teschers with comweats upon such points as the following (I) Proparation, (2) success with pupjis, (3) Att1tude toward work, (4) frofessional apirit, (5) Technical sikil in teaching, (6) Heelth, energy, and personality. Pupils tuition retes, state school laws, city

2 Rules and Reguiations of Spokano, Wash, p.8.

3 Rules and Regulations of Kenses Gity, Mo., p 23. 
ordinances, and atate codes of ethics also appear in some of the booklets.

A few of the handbooks contain irrelevant matter. Occasionally there occur such statements as the followings "No problem in arithmetic is comsidered solved, nor is any computation finished, until it has been proved"4. This, it is self-evident, should appear in the curriculua, instead of in the manuel.

The neceesity of keeping the regulations up-to-date is readily seen in such grovisions a thesa: "Garrying fire-arms or deadly waapons in or about the school buildings or grounds shald be punished with instant disulsal, ${ }^{-5}$ and "Visiting eech other's rooms" (meaning the teachers" visiting) "except on business of the school which cannot be postponed, and all writing snd reading not immediate1y connected with the schools, s1so sewing, knitting, and all work not tending directly to the advancement of their pupils, are postive1y forbidden" ${ }^{n}$. Rules, like these, which are out-of-date, should be repealed and will, no doubt, disappear from the revised booklets. The most praetical provisions for changes in the manuals seem to be blank pages upon which may be written or pasted revisions. Some of the bandbooks list all the schools of the system with their locatione and principals; this appears unwise because the use of names, 2ike the use of dates, makes the booklet go out of date sooner than 1 othervise would.

4 Rules and Regulatione of the Public Schools of Evansvilles Ind.9 p 17.

5 Lanual of the Board of Education of Louisville, Ky., p 33.

6 Rules and Rogulations of Evangvil19, Ind., p 45. 
Several of the manuals reveal the danger of going too much into detail. For example, a statement that the teachers must hold faculty meeting every week may lead to many useless, routina meetings to the injury of teacher morale. The exphasis should be rather upon the positive, professional concept. Minor details ought to be avoided.

No one manual contains all the desirable characteristics; but there is constant improvement, because the later the date of booklet, the more nearly it approsches these criteria. In-as-far as the manuals possess the criteria mentioned in the previous chapter, they are adbering to the standarde set up by authorities in the field .

The handbooks may profitably contain the national or state code of ethics for teachers. As it is now, some of the teachers do not know that their state has a professional code. Adherence to a code helps to make any group prpfessional. When easily available, it acquaints the teachers with acceptable practices. Such aequaintance is desirable, since many ongage in unethical practices simply because they do not know better. This is particularly true of those persons who have only recently entered the organization.

A chart of the administrative organiation is another holpful item which manuals may contain. All official business should be transacted through the proper ehannels, and often teachers without a diagram of the sot-up, do not definitely understend how to proceed with appeals or other comsunications.

7 Van Dyke, G. I., "The Business Administration of City School Systews as Show by Rules and Regulations", The American School Board Journal, Nov. 1930, p 47. 
Apeal must first be made to the official under whose immediate direction the teacher serves if this official fails to satisfy the appellant, the latter should take the matter to the official next higher up, and so on. The plats rohould show the proper 1 ine of communication 7 .

The 8 ources from which the bosrds of education may derive their inforuation upon which policies are based are as follows: (I) annual reports of superintendents (2) books and wagezinea that deal with school administrations (3) regular publications of state education associations and state departments of education; (4) the research bulletins of the National Bducation Association and (5) the yearbooks, research bulletins, and other publications of the U. S. Office of Education. 8 A policy should be determined only after the board of education has studied a.1 the pertinent facts. In some cases the boards evidently have not yet been able to obtain all the facts which bear upon a particular. problem, for often they have not outlined a course of action upon 80me particular point. Consequently, the manuals are not fully adequate when such is the case, but they do serve sowewhat as cowpasses to the teachers.

7 Van Dyke, G. L., "The Business Administration of City School Systems as shown by Rules and Regulations", The Amorican School Board Journal, Nov. 1930, p 47.

8 Adapted from The School Board Lember, Research Bulletin, Vo1. XI, No. I, Natione.I Bducation Association, Washington, D. C., Jan. 1933, p 25. 


\section{Resulta of the Analyses}

Table I p presents a list of manuals analyzed with the dates of their publication and the alse of the cities represented. Especially important in deteraining the significance of the data are the dates of the publication of the rules. These range from 1916 to 2934 ; in every case the booklets with the more recent dates more nearly approach the standards set up by the authorities than do the books that were published some time age.

The systems whose rules and regulations were atudied vary in population from 45,155 to $1,573,985$. Although only eleven percent approximate Louisville in size, this does not affect the study to any marked extent becsuse one of Talbot's Pindings wa that teachers, wherever located, need substantially the same information regardless of the size of the school system with which they are co nneeted. $\mathrm{H}_{4}$ s list of items suggested for inclusion in a manuel shows but little difference in the type of information serviceable to teachers in localities varying in gize from the crossroads village êmploying seven teachers to a city employing three hundred ${ }^{\mathrm{B}}$.

As the manule were studied, it was notices that their terms vary greatly; for Instance, the Board of Education is given, beeides that title, the following ones: Board of School Directors, School Comnitteo, and School Commissioners. The nomenclature of the various departments of the school system differs likewiae.

9 Talbot, G. D. "The Content of Teachers" Handbooks," Educational Research Bulletin, Vol. I, Nov. 10, 1931. 


\begin{tabular}{|c|c|c|c|}
\hline CITY & $\begin{array}{l}\text { POPULATION } \\
1930 \text { CINSUS } \\
\end{array}$ & TITLE & DATE \\
\hline 1. Atlanta, Ga. & 266,559 & $\begin{array}{l}\text { Rules and Regulations of the } \\
\text { Board of Bducation }\end{array}$ & 1927 \\
\hline 2.Baltimore, wd. & 801,741 & $\begin{array}{l}\text { Rules of the Board of School } \\
\text { Comissioners }\end{array}$ & 1929 \\
\hline 3.Cleveland, Ohio & 900,430 & $\begin{array}{l}\text { Administrative Code of the } \\
\text { Board of Bducation }\end{array}$ & 1925 \\
\hline 4.Detroit, uich. & $\mathbf{k}, 573,985$ & $\begin{array}{l}\text { Directory and By-laws of the } \\
\text { Board of Bducation }\end{array}$ & 1933 \\
\hline 5. Hrie, Pa. & 115,922 & $\begin{array}{l}\text { Rules, Regulations, and Reso- } \\
\text { Iutions of the Boerd of Sehool } \\
\text { Directors }\end{array}$ & 1929 \\
\hline 6. Bransvil1e, Ind. & 108,251 & $\begin{array}{l}\text { Rules und Kegulations of the } \\
\text { Public Schools }\end{array}$ & 1930 \\
\hline 7.Hantramek, Mich. & 56,283 & Public School Code & 2928 \\
\hline 8.Indianapolis, Ind. & 364,073 & $\begin{array}{l}\text { Rules of the Board of School } \\
\text { Comalssioners }\end{array}$ & 1931 \\
\hline 9.Jamestown, N. Y. & 45,155 & $\begin{array}{l}\text { Rules and Regulations of the } \\
\text { Publie Schools }\end{array}$ & 1929 \\
\hline 0.Kansas City, Mo. & 392,751 & $\begin{array}{l}\text { Rules and Regulations of the } \\
\text { Schood Distriet }\end{array}$ & 1925 \\
\hline 1.Louisvillo, Ky. & 307,808 & $\begin{array}{l}\text { Rules Governing the Bourd of } \\
\text { Bducation }\end{array}$ & 1916 \\
\hline 2.New Bedford, Hass. & 112,836 & $\begin{array}{l}\text { Rules and Regulations of the } \\
\text { Public Schools. }\end{array}$ & 1922 \\
\hline 3. New Orleang, La. & 455,792 & $\begin{array}{l}\text { Rules and Regulations of the } \\
\text { Orleans Parish School Board }\end{array}$ & 1930 \\
\hline 4.Providence, R. I. & 252,243 & By-Laws and Regulations & 1929 \\
\hline 5.Richmond, V\&. & 182,883 & Rules and Regulations & 1931 \\
\hline 6. Spokane, Wash. & 116,010 & $\begin{array}{l}\text { Rules and Regulations of the } \\
\text { Public Schools }\end{array}$ & 1927 \\
\hline 6. St. Louis, Mo. & 822,032 & $\begin{array}{l}\text { RuIes and Charter of the } \\
\text { Board of Education }\end{array}$ & 1926 \\
\hline 8. Whashington, D. C. & 486,869 & Manual for Teachers & 1932 \\
\hline Indiana & state & Administrative Handbook & 1930 \\
\hline Kentucky & State & $\begin{array}{l}\text { Manual of Organization and } \\
\text { Administration for High Schools }\end{array}$ & 1933 \\
\hline Kentucky & Stato & $\begin{array}{l}\text { School Code (of the Common- } \\
\text { wealth of Kentucky Submitted } \\
\text { to and accepted by the Ky. Cen- }\end{array}$ & 1934 \\
\hline
\end{tabular}


One eity has, In addition to its booklet of rules and regulations, a separate one relating to the examination, certificstion, eaployment, and aalaries of teachers. One manual contains blank pages for revisions; another has sections where new material pay be pasted; while still another has a 100se-leal binder form which provides means for revision.

Often much valuable information should be more logically arranged. The four most usable booklets have both tables of conindises tents and indilentyst percent contain a table of contents and 48 percent have an index. The amall print of one manual renders it a.most usless.

Bighty-three percent contain no policies but have merely rules. By far the most imposing of the manuals, the one frow Hantramclu, Mich. devotes pagest o the Board of Education's philom sophy and polteies and also ineludes trends in education and present-day thought. It contains diagrams of the organization of $b$. mand departments, 1ike the executive, the administrative, and child-accounting - thirty-two in all. It is divided into two divisions: Part I, The Plan and Part II, Means of Procedure. Part II repeata some of the good material of Part I. The great length of the book - 278 pages 6 in. by $9 \frac{1}{4}$ in. - probably renders it less serviceable than it would be, were it shorter. Often the amall booklets contain much valuable, definite information, carefully selected and conelssly stated. Twenty-two percent of the booklets are as gervieeable to a janitor as they are to a teacher, and,in those cases his duties are descri bed vith too much detail, even were the handbook written especiaily for $h$ iw. Fifty percent of the manuals are more serviceable to a member of the Board of Education than to a teacher because more pages are 
devoted to the order of procedure of board meetings than to the duties of the teacher. Two handbooks contain Robert 's rules of order in a condensed form. Half of thes devoto an undue amount of apace to charters of the boards of education and state school laws, to use of the buildings and grounds by outside agencies, and the the regulations regarding janitors. Booklets for teachers should contain only pertinent material that will make thom more efficient claseroom leaders and more intelligent members of the school system.

Table II $p$ showe the topics included in the manuals which were anaiyzed. The personnel grcups and other items are listed.

The personnel groups listed in Table II receive attention from nearly all of the manuals. Richmond, Virginia is theonly eysten that does not have rules reletive to the board of education. Clerks and the business manager aro discussed less fraguently than are any other groups. The topies that occur least frequently are the calender and school boundaries.

Some examples of rules that are too detailed are as follows "Handrails, door knobs, and door-pulls shall be washed with cleaning and disinfecting solution at least once a week and oftener if circumstances require......Deily, at the close of school and on Saturday, Sunday, and holidays, a.l window shades throughout the building are to be drawn halfway; 1.0 .2 to the meeting rail of sash. 20 "The windows must be washed in each of the months of September, December, and April, and at other times when directed by the Superintendent of Kaintenance. The janitor shall during 
Board of Education

Organization

offieers

Funetions

Superintendentduties

Ass't. Superin-

tenderts

Business manager

Supervisors

Prineipals

teachers

Pupils

Clerk:

Attendance Dep ${ }^{\circ}$.

Health Dep't.

Jenitors

Use of School

building

Special Schools

and Classes

Selary Schedule

Calender

Inter-school He-.

lationships$$
8
$$

$x \times x$

$x$

$\mathbf{x}$

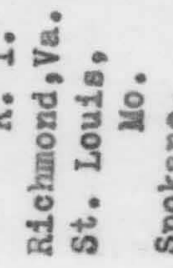

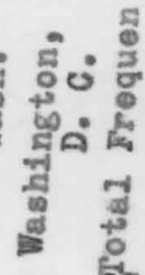

$\begin{array}{llllllllllllll}x & x & x & x & x & x & x & \pi & x & x & x & x & x & x\end{array}$

$\begin{array}{llllllllllllllllllll} & \pi & & x & x & x & x & x & x & x & x & x & x & x & x & & x & x & x & 17\end{array}$

$\begin{array}{llllllllllllllllllll}x & x & x & x & x & x & x & x & x & x & x & x & x & x & & x & x & x & 17\end{array}$

$\begin{array}{lllllllllllllllllllll}x & x & x & x & x & x & x & x & x & x & x & x & x & x & x & x & x & 17\end{array}$

$\begin{array}{llllllllll}x & x & x & x & x & x & x & x & x & x\end{array}$

$\mathbf{x} \quad \mathbf{x}$

$x \quad x$

$\times \quad 12$

$\mathbf{x} \mathbf{x}$

$\begin{array}{lllll}\boldsymbol{x} & \mathbf{x} & \mathbf{x} & \mathbf{x}\end{array}$

$\boldsymbol{x} \quad \boldsymbol{x} \quad \boldsymbol{x}$

11

$\mathbf{x}$

$x \quad x$

x

$x \times \quad x \quad x$

$x \times$

x $\quad x$

$\mathbf{x}$

$x \quad x \quad x$

8

Organization Chart

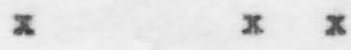

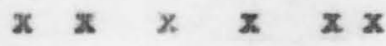

$\begin{array}{lll}\times & 18\end{array}$

$x x \quad x$

$\mathbf{x} x$

$x \quad x x$

$x \boldsymbol{x}$

$\mathbf{x}$

$\boldsymbol{x} \times \boldsymbol{x}^{\mathrm{s}} \mathrm{x}$

$x$

$x x$

$x$

× 16

$\begin{array}{lll}\boldsymbol{x} & \boldsymbol{x} & \boldsymbol{x}\end{array}$

x

$\begin{array}{lllll}x & x & x & x\end{array}$

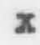

$\times \quad 23$

$x \quad x \quad x$

$x$

$\mathrm{x}$ × $\mathrm{x}$ × $\mathrm{x}$

x 10

$x \quad x$

$x$

Public Relations

$x$

$\begin{array}{lllllllll} & x & x & x & x & x\end{array}$

$x \times x \quad x$

$x$

Viscellaneous

x $x$

X $x \quad x \times x \times x$

$x \quad x$

$x \times x \times$

x $x \quad x$

School lave

$x$

$\begin{array}{llllll}x & x & x & x & x\end{array}$

$\mathbf{x}$

18

School bounderios

x

x $x$

Tuition Rates

2x $x$

$x \times x$

$x \times x$

Philosophy of Education 
these wonths inspect all electric light globes and remove any dust thet may have accumulated"1l. If these detalls are necessary for Janitors, they should be incorporated into a book for cuatodians and should not be included in a handbook for teachers.

A oduliflar criticiam may be mede in regard to rules of order, charters, and Iengthly laws which are found in fifty-six percent of the booklets. Talbot 's 11 at 12 of the date that 302 teachers want Included in a handbookjoes not contain items reforring to laws and charters. Again it way bo said that if such material is to be printed for teachers, it, at least, should not be exbodiad in a manual whose chief purpose is to serve as a quick reforence booklot in regard to the duties of the classroom teacher. If the handbook is to be convenjent and usable, it wust not be bulky, nor must it contain extreaeous watter.

While the regulations must not be too detailed, neither wuat they go to the other extreme and become too general and vague. For Instance, the following ruling is not definite enough: "As an incentive to broader preparation for their work and as a means of stabilizing the teaching stall, the board of education has established rules whereby financial recognition in the way of increased salary is granted to teachers who complete courses of study at approved institutions or under approved instructor in elesses or ganized and conducted $10 \mathrm{ca} .1 y^{\prime \prime} .^{13}$ Whatever the rules are, they

11 Rules and Regulations of Nev Orleans, La.s 73

12 Talbot, George D., "The Content of Teachers " Handbooks," Educational Research Bulletin, Vol. X, No. 10, p258, 1931.

13 Rules and Regulations of Jamestom, N. Y., p 12. 
are not Ineluded here. The reader does not know what the inereased salary is, nor which courses are acceptable.

The handbooks of Hantranck, Michigan and of Washington City are recent and more nearly approximate the criteria of the specialists in the fleld than do any of the others. A regulation from the manual of the latter eity illustrates a guiding principle instead of a rule with set hours; "All teachers will understand that their duties are not confined to the four walls of the classroom. Teachers will be assigned by the principal from time to time to various duties pertaining to playgrounds, Iunch periods, assemblies, and many other building activities. This means that the daily hours of duty for the teacher must be more or 10 s irregular, depending on the extracurricula duties that must be assigned by the principal". Such a statement is better than one that says, "The teacher wust remin in the building t111 three thirty or a half hour after the pupils leave" or soaething similar. The general eritieism that could be made is that there are too wany detailed rules and not enough guiding principles. A careIul analysis forces one to conclude that, although the existing handbooks are holprul to teachers, most of the booklets fall short of maximum usefulness. Revision of many would bring them up to the standard, set by Talbot and others authorities. 
THE BOARD OF RDUCATIONS POLTCIBS TOWARD THE PUPILS

The board of education establishes the polleies of the school oystem; therefore, in order for the teachers to carry out intell1gently these plans, they should understand the educationel philosophy which motivates the policies. ${ }^{2}$ The necessity of cooperation on the part of the entire teaching staff is so obvious that it is Ijkely to be underestinated. Oneness of purpose, realised through the cooperation of all the ataff, not only increases the joy of the work of the systes but also prevents educational 10s8. A few workers out of harwony with the common aims of the organization mar the entire spirit and decrease the efficiency.

Bducation is no longer looked upon as an accumulation of knowledge. The mastery of facts is not considered one of the main objectives of present-day schooling. While teachers have outgrown the concepts that education is preparation or formal disciplines wany are not clear as to its chief aims. If questioned, some could give only intangible generalities which could not, in any way, serve as guiding plilicies in their teaching. Nany teachers have not pursued courses in administration and in the philosophy of education. Some have not read deeply enough to have formulated thoir own philosophies; nor do they know the philosophy that prongtis the action of the board of edueation and the superintendent. Consequently raany teachers cannot earry out the polleles of the board of oducation as wisely as they otherwise could. 1 The Fublic School Code of Hamtramek, Mich., $\mathrm{p} 22$. 
A study of the polieies of these boards of education whose manuals are listed in Table I, showa that tweaty percent of then explicitly state that they are guided by the principles of applied psychology as regards their purposes, scope, and procedure. First of all, they recognise the human eleaent in all relationshipo throughout the teaching profession. Pupils, teachers, and supervislors are all individuals to them, and are considored more inportant than curricula, methods, and even budgets. Washington City and Hentranck, Hich., are especially clear in the statment of their attitudes. Some of the other cities studied leave one to read between the lines of their manuals.

The teachers ${ }^{\circ}$ methods and emphasis, in fact, their attitude and professional spirit will be shaped largely by the policies of the board of education. For instance, the curriculum of a systen that has for its guiding prineiples such ideas as that activities used on life situations should be selected according to the interests, needs and abilities of the individual pupils and that the subject natter taught should have for its core an understanding of the problews of present day life wil differ largely from the course of study used in schools that do not omphasise euch principles.

The teachers outlook will be broader if their board of adueation believes that the schools should foster a spirit of goodwill and friendiliness on the part of every pupil, not only toward the members of his ow community, but also toward those of other nations. In shert, the teachers must understand the administra-

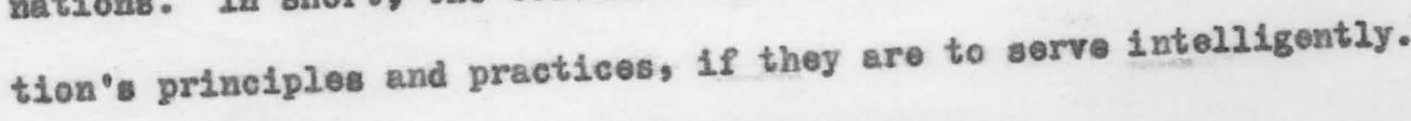


Fist the ettitude of the board of education toward the pupila should be noticed. Up-to-date administrators accept the four main principles underlying the Dewey philosophy, namely:

1. The school should be chlld-centered, that 1s, attention is focussed on the nature and needs of the child.

2. Hducetion is considered a process of experiencing it is an active and a continuou reconstruction of experiences, Since education is a process of experiencing, and one learn by doing, then thinge wust be arrenged in the school so that the child may learn through experiences. The work of the school reust be judged by the growth of the pupils in their power to meet new situations and in the variety of their interests ${ }^{1}$.

3. The doctrine of interest and effort is upheld. Dmphasis should be placed upon the fact that the theory of interest includes a theory of effort. The school should remove those obstructions which would discourage effort, but should Ieave enough others to wake the adventure interesting. In the gave of atudy, as in any other game, the $\mathrm{p}$ upil should encounter diffeulties with the will to win. Thus education will be raised from boredow to an exeiting edventure.

4. The school is "inherently a part of the total soclal process -- an embryonic comeranity life, active with types of occupation that raflect the life of the larger society and permeated thoughout vith the spirit of art, history, and scjence". 2

1 Adapted from Wanual for Teschors of Washington, D. C., p 28 Condensed Irom Hamtramek Public School Codes p 14. 
The school geoks to place children in possession of

their social inheritance and to develop their ereative gowers.

In the present-day school the development of proper hatits, attitudes, and interests is considered of utmoat importence. The underlying philosophy is that every child should be given an opportunity to live richly and happily as a child, that each one ehould be brought to desire the better things of life, not only for hieself, but for the group of which he is a part. In other words, the echool is expected to teech the pupils to build up health, to value the fine art of living together, to learn citizenship by precticing it in the school, to desire to keap on learning, to employ the higher uses of leisure, and, above a.21, to develop fine character. Wise boards of education believe that education is that development of the individuel which fits him to 1ive well In oceial environment, and thus to contribute to that enviroment by doing efficiently the things which he needs to do now and will most Iikely need to do 1 ater ${ }^{3}$.

Another one of the chief objectives of education is to enable the Individus through reflective thinking to direct his own life Into socially useful channels. Agein this education comes through experiencing. It is largely useless to toach about morels or ethics. The school must present opportunitios for esch child to make cholces in his conduct, and it must encourage the good cholees and discourage the bad onces. Mifty percent of the boards of education, recognizing this need, erphasize the value of elubs and pupil-controlled activities, wherein the child learns good social 
conduct in Iifo-like situations. The term citisenship is frequently used in schools to denote work in charecter developnent. Puplis are marked "satisfactory" or "unsatisfactory" in such qualities as courtesy, qooperation, self-control, reliability, and helpful initiative. The tendency is to olininate exact marks. "Satisfactory" means that the child is doing as well as could bo reasonably expected, taking into consideration his mentality, hle health, and his emotional poise.

Corporal punishment is restricted by wll the school systems studied. Public opinion holds that it should seldom be employed by the teacher, at least not without consultation with the principal, and Its use is to be atoided whenever possible. The old formal, arbitrary type of discipline disappears when the school is regarded as an embryonic community. The good citizen is not one for whose every stop a chart must be provided by some authority, but he is the one who, self-directed and self-controlled, weete each life situation, expected or unuaual, with cheerful comon sense and the use of constructive thinking. Hence the pupil must be given the opportunity to become self-controlled and selfo disciplined. That the boarde of education feal self-discipline on the part of pupils to be desirable may be seen from their rules in regard to axbitrary discipline on the part of teachers. Nearly all the manuals contaln a ruling similar to this "Corporel punishment way be used only in cases of great urgeney. Fach teacher shall wake out a full and complete statement in writing of each case in which corporal punishwent has been administered, by his upon any pupil, specifying the name, age and grade of the pupil punished, the offense charged, and the kind and degree of punishgent inflicted and the name of every person who witnessed such punishment, which statement shall be given to the principal to 
be forwarded by hil Lwadiately to the Superintendent of Schools ${ }^{4}$ : Wighty-nine percent of the manuals say that corporal puniahment way be given only with the witten consent of the parent or guaro dian. Ninety-five percent limit it to administration by the principal. The idea, of course, is to train citisens who will not have to be controlled by outside forces but who can govern themเอ1vอร .

Both currieulum and method should be such that the pupil learne how to think rather than what to think. The school subjecta are woven about a theme vitalized by a real interest. The aubject atter is not learned or memorized because the teacher requires it, or beceuse the pupils want to be promoted, or in order that they may get good marks, but the curriculum should be lived, experienced, purgued for the joy of the pursuit, and the learner apurred on by the curiosity inherent in overy child. The curriculua should be stimulated by interest, and vitalized by reality. The child ' interests which have leading-on qualities that are desirable should wake up the eurrieulum. Harap, Hopkins, Briggs, and other curriculum experts agree that "the objectives of education are all the activities which ought to make the totality of human Iife from birth to death ${ }^{5}$.

A rodern school system provides, firgt of all, an extensive health program which includes free medical exanination, free clinical treatwent when necessury, truining in health habits and atiftudes and the breaking dow of superstitions and false ideas ostablished through comercialian. Safety education must also

4 Rules and Regulations of the Bosd of Bducation of Allante, Ga.s p 33. 
perweate the 11fe of the child. Boards formerly stated their prineiples rather negatively. For instance, Louisvillo 8 outof-date manual says, "Wo pupil shall be detained d\$ any regular recess, and no pupil shall be confined in the school room for more than two consecutive hours vithout exercise in the open air, except on account of the inclemency of the weather ${ }^{6}$. Now the bulletins from the superintendent's office are stated postively in regard to the child's health and care. The school wust consider the whole childs it must be interested in his mental as woll as it his physicel health, for the central task of the school is to develog fine humenized individuals. The emotions count as deeply as do Intellects 3 they determine whother Individuals are to be happy within themselves and within their environment with the native equipment with which they have ontered lifo. The attitudes of facing problems squarely, of accepting or adapting what cannot be changed, and of considering the other person, must come from a bealthy training of the emotions.

Learning belongs to every stage of life, and each stage should be given the education that it needs for its own profit and full enjoyment. Children should be taught to live rightly, intelligently, and happily as children, because living fully in the present is the best preparation for living adequately in the future. Pupils need to be heppy and to have a sense of security. Bducacation should be a joyous process, because joy is the only soil out of which fine personality can flower. To quote Angelo Patri, 
"School must be the kind of plece that permits full, brave, darIng living"----the kind of living that onables pupils to have faith in themselves and in each other.

The school should give the pupil training in the needed soeial traits. It should provide him with social situations which he may learn to handle successfully. Failure breeds more failure and inferiority couplexes, while success leads on to success. Bach pupil must be helped to succeed with his school duties and with his extra school obligations to his family, to the traffle officer, to the librarian, and to all the rest."

Intelligent boards of education feel that few normal puplls should be allowed to fail in a grade and so be compelled to repeat the work. Such pupils may form the habit of failing or of considering themselves failures. The repetition of a grade is the remedy for poor work; the eure is greater stress on the fundemental principles of instruction, and more individual work upon these unueval cases. Aside fror the discouragement that may arise from nun-promotion, repeating a lower grade often results in thepupil's secrlfieing the opgortunity to experience one of the high grades. According to the 1 deas of 20 percent of the beends of education, non-promotion is an indictment of one of the following:

1. The school system and its philosophy.

2. The partieular school and its organisation or administration.

3. The curriculum of the grade or the ability of the teacher.

7 Directory and By-Laws of the Board of Edueation of Dotroit, Wich.9 $p \cdot \overline{2}$. 
One of the booklets expresses the idea of the majority of the analyzed wanuls in this ways "Fromotions should bo made from grade to grade at any tiwe; gradual promotions, in which a pupil works graduslly Irom one grade to the next, by taking in the high grade such subjects as he is able to carry, are to be encouraged. Rapecial attention is to be paid to the progress through the grades of baekward and over-age pupils to see that they do not become discouraged through repeated failures of promotion and finelly come to a mere waste of time in the formallty of repeatIng grades; no less attention is to be paid to the progress of especiully gifted pupils to see that they are not encouraged to form habits of Indifferent effort and 1dleness through rotention in grades in which the work is below their eapacity." ${ }^{8}$

As Dr. Strayer skys, "giducation is for anceess". Needless to add, $\mathrm{Dr}$. Strayer means rexl achievement, not sentimentel approval of poor accomplishment. The only measure that can be reasonably applied to the work of any individual is that wich asks that he do the best he can. In an American school, failure and repetition are becoming abnormal. A ohild can not experience a feeling of success if he is kept working hidf-heartediy at the same 01d, halp-mastered tesks. An enriched program for the superLor child, rather than the skipping of grades and early graduation, is advisable, because acceleration of the gifted child usually leads to sociel mul-adjustzent.

The fdeals of a democracy require that the school adjest its etanderds to the pupils " abilities, interests, and onviromentel conditions. This policy results in a meried variation in curricuJum content and oven in different types of schools, especially 
high schools. Bquality, not identity, of oducetional opportunity for each child is sought. Adaptability of subject-watter content is vastly more importaht than is mastery of routine.

Since the school program should be individual 10 , so that each child will experience a sense of achievement, satisfaction, and security, the teacher must discover the pupila abilitios and their individual differences. A teating program consisting of tests of mental ability modern boards of education. The mental tests provide for ability grouping in order to improve the service of the school to the individual pupils through adjuatwent in the time spent on a given unit of subject watter, through adjugtmeat of subject matter 1tgelf, and through adjustment in the pupil'o programs. Homogeneous grouping encourages exch child to work to his maximel ability. When arranging groups, in addition to intelligence and previous achievenent, other pertinent Pactors, such as interests, attitudes, and health of the individual, should be coasidered. Even homogenous classification does not do away with the need for individual teaching, beceuse nature has sean to it that no two ehildren areilalike ${ }^{11}$.

Realiaing that we live in a dynemic, not a static society, progressive beards of education promote a guidance program. They feel that the school must endeavor to keep square pegs out of round holes, and that it must accordingly give pupils the chance to derelop their rael inclinations, interests, and abilities. A child

9 Adapted from Bulletin to Parents of High School Pupils of LouLsvi110, Ky., May 1931 .

10 Waits, H. E., Practical Problems of the School, Benj. H. Sanborn, Chicego, 1922, p 3.

11 Wort, Paul R., The Individual Pupil, Anerican Book Co., Cincinnati, 1928, p 17-371. 
should be so trained in his power of adaptation that he will not become subject to a Iate imposed upon him but will be enabled to help ahape his own eareer. He should not have ideas forced upon his but should be taught to develop his own opinions, which, even when formed, are to bo held tentatively. For this rason, fifty percent of the boards of educetion have ruled in their aanuale that the Bible must be reed without conaeat. 12 All teachers ehsll carefully guard against the introduction of questions of sectarian or partisan political nature" is one handbook's way of expressing the thought that is found in every one that was studied. If the boards could feel sure that teachers would present both sides of controveralal questions, they would not have rulings against such problems. No doubt, they fear that aome teachers would foreibly present but one side of a question and would try to prejudice the pupils. The ideal gituation would be to have both sides of controveraial questions clear2y presented and then to allow the pupil to fore his own opinios. In this matter, philosophy has outrun practice.

The school keeds to cooperate with ageneies ilke the 1 ibrary, auseun, press, and other educationsl assets of the connunity. "The cooperation of a.l the other local educational agencies - ohome, church, press, social centers, theatre, etc.,---should be encouraged and secured as far as possible. n $^{23}$ Some cities, as, for examplo, Louisville, have arranged with the elty library for the loan of a large number of books to be exchanged periodicaliy: while often teachero have a definite sehedule for accorpaning their classes Rules and Regulations of Spokane Public Schools, p 23. Igginton, Daniel P., "American School Board Journal, Mar. 1934, g 10. 
during achool houra to the eity library for study or for free reading. On the other hand, however, the school must avoid besing used by propagandists or comaerclal agents. ${ }^{14}$ Nor should the school atterpt to touch what other agencies can teach bettor. Ibxtracurrieular activities form enother phase of the augsented program of the school. Clubs, orchestras, and other school organizations are used as a means of broadening the horizon, of atimulating new interests, and of promoting teawork throughout the entire systare. The use of the radio has proved of inestimable value in giving breadth of outlook. The raide has been described as the "fourth $\mathrm{R}^{n}$. It gives the child viewpoints other than those of his teacher; it develops new life; it gets hold of that otheral element know as the lagination. It enables the pupils to have aubjects like music or science, for instance, teught by experts. Bxploratory courses in the junior high school riveal to the pupil his interests and, in a general way, his aptitudes. Ao Goodwin Watgon aptly said, they are "a sort of cafeteria of deairable experiences", and they allow the p upil to do well that sort of thing which he would otherwise do in an inferior way. These coures widen and deepen the pupil's experiences; they also implant the idea of the glory of work and a wholesome respect for a.l typas of Iabor.

The new economic order has brought the ehallenge of the use of lisure time. The school must help so that leisure may be apent with pleasure and with profit. The modern movie wust be considered the current magasine cannot be ignored; games for

14. Rules and Regulations of Spolene - Washington, p 23. 
informal groups must be taught. Commeriealised reereations have been taking up too much of the leisure time of the Anerican people. Intelligont boards of edueation have decided that many former athletic programs have entirely overlooked the real needs of physical educetion and have provided games where a fow participated; while wost of the students have been merely spectators. Those boards feel now that presentday education needs to offer activities of many wholesome kinds at the schoel, but it also needs to provide for a continuance of high-grade anbivity on the part of the individuel during exill the hours when he is outside the shool. Consequentiy, group gamea are superseding orgenized athleties, and discuseion elubs are taking the place of formal debates, for recreational provision must be made for the participation of the entire group instesd of for the fow. An analysia of the handbooks of typical schools shows that thirty-three percent of the systeme allow the departwent of recreation to use the school bulldinga and grounds; e.lthough in muy cases, es in Loulsvilie, thers could be a still closer relationship between the educational and recreational departments.

From the principles that the pupil learns through purposeful participation in experience and that he can learn only by his own aetivities, it followe that he should be afforded zunerous notivated situatione and self-directed activities. The suefessful boards of educetion desire these ends beceuse they think the true purpoes of education to be the development of evch pupil in all his potentialitịes as a happy, contributing nember of socisty. These ideas are in harwony with the tenets of eductional philosophy. To use F. Ao $^{\circ}$ MeCall'o words, "The pupil is the center of gravity or gum of the educational syater....All the paraphernalia of education exist for 
just one purpose, to wake desirable changes in pupils". 15

It may be said, in conclusion, that what the boards do not say about pupils is probably as significant as many of the statements that are recorded in the booklets of regulations. The very absenee of rules often implies a large degree of freodom. Bven then, the boards of education in their attitude toward the pupils lag far behind present-day philosophy of education.

15 MeCall, w. A., How to Measure in Edueation, Mecmillan Co., 1923, p 6. 


\section{THE BOARD'S ATTITUDE TOWARD TEACHIRRS}

Most handbooks for teachers do, and all should, reIlect the boarda of education's attitude toward teachers. Do they believe in allowing teachers to partieipate in the administration of the school as far as is practical, or must all the plans come from above? Is the teacher considered a thinking personality or a mere $\operatorname{cog}$ in the wheel?

The tendency toward the wider diffusion of administrative rights and responsibilities has been under way in education as well as in other walks of life for a half a century; however, there are atill various types of Administrative systems, ranging frow the highly centralized, autocratie kind where there is no voluntary cooperation, to the diffused type. Many schools heve an intermediate type wherein a little field of authority 18 reserved to every one in the systems and within his own field each is supreme but is responsible to seme one else. This decentralized plan stimulates the teachers to greater orginality and exertion. Bven in the most highly centralized systems there is some degree of teacher participation in the adninistration of the school. Such participation has usually been by means of the informal discussion.

This attitude is in keoping with educational literature which says that sound school administration must give major attention to the nature and needs of the teaching staff. It cannot treat its teachers as if they were unakilled laborers working by the hour 1 Clark, M. G., "The Part the Teachers Should Play in School Adeinistretion", American School Board Journal, Aug., 1920, p 40. 
In a wholly impersonal relationship with their employers ${ }^{2}$. Nothing has yet repleced the human touch in personnel administration as an effective builder and conserver of high morel among workers. 3

Professor Sears 4 , in a thorough atudy of the work of a hundred councils for teachers, found that almost every problem of school administration has been touched upon by them. Their contributions have been worthy and have met with official approval. Their work included the following: making courses of study, adopting teacherruting plans, getting a teacher's pension law adopted, selecting textbooks, arranging for extension courses, assisting in issuing bulletins on many educational subject, helping to raise epeciel taxes for school purposes, and formulating or revising manusls for teachers. The peport is general that improvement has resulted from these activities. The morale of the staff is increased the central authorities and the teachers understand ach other better, because each group has gained something from the view point of the other.

As a democracy signifies that the individuel shall have a share in determining the aims and conditions of his own work, so It demands that teachers share in the planning and directing of education. The right to plan, necessarily, carries with it corre sponding responsibilities, Iike the obligations to critise cone structively rather than destructively and to cooperate fully in carrying out the will of the majority.

2 "Adwinistrative Practices Affecting Classroom Teachers", Part I: "The Selectioh and Appointment of Teachers", Research Bulletin, National Bducation Association, Vol. $\mathrm{X}$, No. I, Jan. 1982, p 3.

3 "Administrative Practices Affecting Classroom Teacherg", Part II: The Retention, Promotian, and Improvement of Teachers, Research Bulletin, National Education Association, Vol. $X_{0}$ No. 1, Mar. 1932, p 61

4 Sears, J. B., "Teachers" Councils", American School Board Journal, Jan., 1924, p 52. 
Participation in the administration of the school increases the educational knowledge of the teachers. Teacher activity in the profession is as imperative as pupil activity in the schoolroof. Learning by dolng is a well-recognized principle in the school system. An understanding of the educational progrem is necessary in order for the teacher to cooperate most successfully In its realization. The classroon teacher also needs the broad outlook in education that is gained through helping to plan and carry out the whole general program.

Another advantage is the added satisfaction which teacher find in their work. They are no longer mechanical automatons but are directing forces in the system. There is a feeling of freedom of good will toward others, and a sense of creative endeavor.

The teachers ${ }^{\circ}$ added knowledge with their practical point of view helps to rake the schools more efficient. Their elose touch with the needs of the pupils prevents the launching of Impractical plans and prograns that are not reasible. It goes without arying that teachers are more cooperative in carrying out programs which they have helped to form. The administrative stall of Louisville, for ewample, says thet the teachers are using the courses of tudy, which were formulated by groups of their own members, much enthusiastically and intelligently then they have over used any other courses.

A study of the principles of boards of education proves that the majority of them feel that teachers are, after all, the ind.spคnaable and most essential factors in an educational systom. The success or failure of any unit of the organisation depends ultimately upon them, for several reasons. First, there is the influence of their personalities. Secondly, they are responsible 
for the 2 ife of the school which, in turn, affects the individual pupils. Thirdly, it dependa largely upon thom whether or not desirable ideals, attitudes, and habits are acquired by the pupilo as by-products of their studies.

A survey of teachers' qualificstions, certification, and salary schedules, as approved by school boards, shows that a paramount problem in public education is to secure for every classroom a competent leader who ean cr6ate worthy ideals, right attitudes, and permanent life interests. With a dynawic conception of education, school boards and superintendents expect the teachers themselves to continue to grow and develor, because the teacher so largely determines the character of the school. To quote one manual, "The teacher is the most important single factor contributing to the sacese of the school" ${ }^{5}$

To be well propared, the teacher must know the principles of humen behavior, mast understand child psychology and aental hyglene, and wust apply case-work methods. As one system describes her, "A superior teacher is one who renders superior service to the child whom she teaches, to the school in which she works, and to the eomunity which she serves. A superior teacher is one who possesses broad acholarship who is throughly familiar with present dey educational theory and practice in the line of work which she teaches; who is doing constructive educational work where she is employed who is actively promoting the educational welfare of the compunity in the vieinity of her achoo $1^{10}$. Accordingly, a stalf of supervisors is waintained whose sole purpose is to increase the teacher's officiency. Rating scales 
and salary schedules in most of the progressive systems recognize the value to the teacher of travel and of continual professionel atudy. While the teachers are expected to give attention to their professional improvement, most systems, however, warn them not to undertake so much study that their classroom efficiency will will be in any way impaired. The teacher is also provided other means of improvement in service besides study, for example, faculty meetings, conferences, demonstration lessons, visiting schools, conventions, reading podagogical books and magazines, and curriculum revision.

Kany cities have adopted the policy of leave-of-absence for study or travel. It is generally understood that a sound preparation will carry over for the first six or seven years of professional activity, since a teacher fresh from normel school or university can teach that long without becoming too stale. This fact has caused loaves-of-absence to be known as sabbetical leaves, and the rule generally is that no leave-of-abence shall be granted to any teacher who has been in the service less then seven years. The developments in the science of education and the changing conditions of civilization make in-gervice education very important. Since so much is expected of the teachers, thoir training wust be continuous. They should make systematic attempts to keep abreast of the times and endeavor to increese their understanding of the world in which they live. The jvansville, Indiana system gives bonuses for credits earned each year by the teachers; for "gelsSgprovemeat", Kansae City, Missouri increases the salary, as do the majority of the cities. 
School boards that control treining or normal sehools for teachers have, in general, a progran of study with the following functions:

1. To assiat in the forwulation of a philosophy of education.

2. To provide an understanding of child nature.

3. To give mastery of subject matter.

4. To develop powers of evaluation in curriculug and in methods.

5. To train in professional othics.

6. To educete for life outside of the classroom?

The Gleveland and Detroit manuale list specific courses required by their Teachers" Colleges, but the curricula of all normal schools are rather similar. The last objective in the 1ist, nemely to educate for life outside the schoolroon, is isportant, although it has not boen mentioned oariler in this study. By leadership and augzestion, teachers want to do better. The right kind of leadership ean eame ondy from those individuals who are themselves living sull, rich lives. They sust have new thought each day and express therselves in new ways. They muat value truth above doetrines and dognas and have convictions that are subjeet to change in the light of new facts.

While this subtle leadership constitutes the essence of ert in teaching, a knowiedge of skillful technique wakes the work seientific. All boards of educetion in large cities belleve in a testing progrea, whereby every child is better undergtoods instruction is improved; and the teacher's work is Judged objective1y. This plan helps to provent the superior pupil from loafing, keeps the slow one from becoming discouraged, since he can be given

7 Directory and By-Laws of Dotroit, Michs, p 92. 
suitable assigmants, and enables the teachers to have each pupil work to his limit. It is the teacher"s duty to watch for various personalities and not to expect them all to travel at the seme rate or even along the same road. Mental tests yield intelligence quotients; achievement tests, given after the mental ones? reveal educational quotients; then intelligence quotients divided by educational quotients show the achievament quotients which rank the teacher's eork. The teachers are not doing their full duty, if the achievement quotient is below par. "Bvery teacher should become familiar with the recently developed tests and psychological aids for training the children in proper mental habits, and she should use that knowledge in her classroom daily ${ }^{108}$.

Thirty-zine percent of the boards of education represented by handbooks require candidates for teaching to pass physical extaminations. This practice is in agreement with good sducational practice. Sears says, "The tendency among cities is to insist upon a health certificate, based upon a thorough physical examination, as a part of every applieation for a teaching position ${ }^{9}$.

Physical fitness is desirable; scholorship is admirable; but attractive personelity or bigness of spirit is even more necesgary. Some Boards of Fducation consider voice, appearance, tect, enthusiasm, and alf-reliance important factors of personality ${ }^{10}$. Such an attitude corresponds with the ideas of Frank Clapp, Thomse Risk, and others who feel that the character of the teaching voice greatly affects the emotional responses of the pupils, that the teacher's generel appearance, especial.ly in matters of dress,

8 Bules and Regulations of Kvansvi.110, Ind.9 p 18. 
should make positive appeal to the esthetic sense of the child, and that tact is a measure of one's social intelligence. ${ }^{11}$ These points are written in rating selles, rather than in rulings for teachers, although one eity saya, "Teachers are required to be neatly and modestly attired". 12

Frov the principles that the gupli learns through purposeful participation in experiences, and that he can learn only by his own activities, it follows that the teachers ${ }^{\circ}$ primary function is to stiwulste, guide, and direct the solf-ectivity of the pupil. All administretors agree that the taechers must, therefore, furnish favorable conditions for legrning ${ }^{13}$. It becomes their duty to provide the proper fhysical conditams of the room. The temperature aust be regular, the lighting auficient, and the ventiletion adequate. ${ }^{14}$ Anong the duties of tetichers rentioned in every handbook, one finds that they axe to see that the room tenperature is maintained near 688 or $70^{\circ}$, while they se elso responsible for the care of a.1 the room equipment. Order must be maintained. Equipment, like cherts, globes, reference matter, ond other meterial for instructional purposes, should be in its appointed place and be handled intelizentiy.

It is fundementral in a denocracy that all. children receive a fair chances therefore, evory child of school age should be easily accounted for and should receive his share of the offerings of the school; honce a careful keeping of records is required of teacherg.

13 Glagp, Frank L. and Risk, Mhowas K., Better Toaching, Silver, Burdett and Co.s p. 24-28.

Waits, H. B., Practicel problems of the School, Benj. H. Samborn \& Go., Chicago, 1922, p 64-66. Strobel, R. Fo, and Morehart, G. C., The Nature end Meaning of Teaching, i 78-82. 
A.1 but a few boards of education realize the fact that between what the law requires as a minimum from teachers and what it is possibie to do, there is a wide margin. Fithin this broad araa, tney are glad for the teacher to use initiatige and to work out nev and better ways of teaching ${ }^{15}$. Half of the manuale studied reveal their Boards" tendency to give teachers a place in the oducatiobal sum and to heop tham have a highly professional attitude toward their work. The sections upon reguirements, rating, and professional advancenent show that boards of edueation in line with good educstional practice, consider the minimum essentials of a teacher to be character, cultural background, and the spirlt of professional advaneement. The teacher must study constantly to keop abreast of the times and to keep in touch with oduestional developments ${ }^{16}$, hence increaments of salary are ind1cated for improvenent by a fourth of the manuals. 17

In granting the superintendent the power to change the teachar's position, if he thinks fit, the school board recognises the principle that teachers are individuale with different abilities and interests which may change with time. Forty-four percent of the boards have regulations regarding promotion and transfer of teachers and make an effort to plece thom where they can work most effectively. In fact, that proportion of the bourds seem to recognize

15 Adapted Prom Talbot, George, D., "The Content of Teachers" Handbookg". Bducational Resparch Bulletin, Vol. X, No. 10, 1931.

26 Strobed, R. F. and lorehart, G. C., The Nature and Neaning of Teaching, HeGraw-Hill Co., New York, 2929, p 252-262.

17 Rules and Regulations of Atianta, Ga., p 26. 
tho human element and have borrowed fros business a technique of personnel administration and supervision. This is revoalod clearly in their regulations relative to the functions of supervisors. 18

The wanuals of Hamtranck, Mich., Bransville, Ind., and Washington City show that theix bourde of education consider toachers a. personalities, not werely paid employoos. The other citiea reveal this tendency also but in a small degres. Boards of edueation do not approach modorn educational philosophy as closoly In regard to their teachers as they do in the case of pupils. Howover, when the oighteen manuals studied are arranged chronologically, a decided contraet is seen to exist between the older ones and those of receat date, Inasuch as their attitude toward the tescher is concerned. In the agent that turns the wheel, not just a were $\operatorname{cog}$ in the wheel. 
OFAPTER $V$

\section{THE BOARD'S RELATIONS WITH THE PUBLIC}

The people declare their faith in public education as a means of safe-guarding the public wolfare and of promoting human progress. They put their responsibility for its organisation In the hands of the boards of education whose duty it is to earry out the eduartionsl plan within the community. The board of education, in turn, elects the superintendent whe is ita executive agent and the advisory officer of the school systes. It also adopts rules and regulation designed to guide the superintendent in the discharge of his dutios. The superintendent is directly accountable to the board, who is likewise responsible to the public. Since the board's authority comes from the people, It is the menbers' duty to carry out the plan of tho people faithPully and consiatently. 1

There is only one sound fuatification for the provision of froe education at public expensa, and this is that it mey make ach individual better able to contribute to the improvement of society ${ }^{2}$. As long as there is general taxation for achools, the bourds of education feel that they wast give to each child what will entable hin to bocosie a better citizen. The raci mission of of the school is, in 1 ts final purpose, not alone increased Intolligance and alder diffueion of knowlodge, but the msking of better men and women, and the developmont of highor stendards

1 Resder, Ward G., The Fundamentals of Public School Administration, Hacmilian Co., New Yorik, 1930, p 15-19

2 Administretive Gode of the Board of Bducstion, cleveland, Ohio, p 89. 
of the social and eivic order, or, in other words, the chief function of the school is to enable the child to live a normelly satisfactory life for himself and to contribute his full share toward social progress. ${ }^{3}$

Education has become more vital to social progress as society has become more complex; since man's chief problem now is control, not of natuse, but of man himself, education must become increasingly social. The public demands that the child be taught the social attitudes and ideals necessary for society ${ }^{\circ}$ progressive continuance as well as the knowledge and akills essential for the individual's functioning suecessfully. It asks the school to develop pupils into cooperative and useful eitizens of their community and of the world, to fit then to live happily in the present order and at the same time to be able to improve that order.

So that social integration may be attained, the school must strive to enable pupils to think through matters, to base their opinions upon unprejudiced ideas, and to hold them tentatively. Tolerance and hope should be encouraged, and fear cast out. The school must help the individual fight the danger of being overwhelmed by industry or by eity life with its political losses. Bach person should feel that he, though he is but one, does count. The shool must give the pupils a sense of power as individuals and wust train them in self-criticism, in initiative, and in adaptability, if they are to become worthy members of society. tion, Ginn \& Co., Bostoh, 1931, p 18-23. 
Although dewocracy roquires that pupils should think for themselves; there the individualistic aim stops, because they wast learn to act with others. They wust be trained in cooperation and organimation in order to combet disease, poverty, Iow ideals, and otherflils that threaten democracy.

Boards of education owe it to taxpayers that they turn a deaf ear to all forms of propaganda. Schools must not be used by advertisers. The syatem is to do only those things that cannot more secessfully be done on the outside. "Outside organisations should not regard the public schools as places for spreading propaganda" is the thought expressed in all the handbooks.

The public school should be eon-politieal and non-sectarian: accordingly the boards wust be alert to koep out of the classrooms all political and sectarian matters. When the Boards say, "Controversial subjects have no place in the schools $10^{4}$, they are in pratice a step behind the philosophy of authorities. Here is a specific spot wherein the public needs educating.

The public hes a right to ask the school administrators to keep the school in touch with the present, and to reflect the. rapid changes that are taking place in the world. Since learning accompanios only auccessful experiences, situations must be set that give pupils a sense of satisfactory achievenent, and since the school wust be sensitive to the ever changing conditions of society, the curriculum must be in a state of continuous revision.

The public looks upon the school a a potent agency of change. A better tomorrow demands that the school be concerned with the woral issues of waking a 1ife. No amount of knovledge will make a Indiane, 48 , 
desirable citizen unless he makes vise use of his learning. What he does with his knowledge is largely a matter of emotional control; consequently the school must provide situations for emotional growth. Character development becomes a goal, not almply a byproduct. The public is also asking the school, in addition to training the pupils for seccessful home and community membership, for education that will make them world-minded and appreciative of the contributions of all nations.

Because all classes contribute to the school's finences, and "because the supreme function of public schools is the education of all individuals so that they may live succesafully in a democracye5, it is the duty of the board of education to insist that every employea secure the cooperation of all petrons, and that they show no partiality on account of the high social standing of some parents, or want of sympathy because of the low social rating of others.

The board of education must no longer be interested merely In the education of children, for it owes a duty to sdults ss well. Continuation, evening schools, and other provisions for those whe want further education are due the people, whenever the finences are sufficient. 6

Bosids of education must interpret the schools to the community and explain the meaning and significance of the larger policies that the administretors are trying to put in force for the city a whole. They must give the public sorse idea of the activities and educational possibilities of the system and rust acquaint it with

5 The Public School Code of Hamtranck, Michigan, p 68

6 Cubberley, E. P., State School Administration, Houghton, Mifflin Co., 1927, p 158-161. 
the needs of the school and the use to which the funds are put. "Parents and other adult nembers will be kept informed of the purpose, conditions, and needs of their public achools through overy available agent and agency". The agents participating in this task will be mabbers of the board of education, the superintendent, the executive staff, principals, and teachers, custodians other operating employees, and the school children. The agencies involved are: the newspapera, printed bulletins to parents, the parent-teacher associations, school programs, commencement, visitting days, home contacts by vislting teacher and school nurse, the school building, social contacts and other visual, oral, and written means $\mathrm{m}^{7}$.

This is done by publieity in the newspapers, by means of radio programs, exhibits, and visitatioh days, as well as through parent-teacher organizations and workiaf visiting teachers. The public should be informed of the school's building program, the necessity for frequent changes of textbooks, and statistics which compare the cost of education with that of commodities and 1 uxuries.

As the school must allow the child to do what he finds interesting, but at the same time must refine these intersts; so must the board do for the school what the public desires, and yet all the while, it wust influence and probably improve these desires. 8 Iecording to Nichlos Lurray Butler: "The proper function for a board of education is not to administer the school in detail, but to represent in board, catholic, and generous spirit the public opinion of the community, to select the experts to fill the

7 The Public School Gode of Hamtremck, Mich., p 269 
chief posts in the school systers, and to sit in judgment upon their recomendations; to check those experts when in their exuberance and onthusiasm they make proposals which public opinion will not suatain, or of which the public treasury cannot bear the cost, and to spur them on whenever they seem to lag or to lack wisdow or seal".

The board aembers, according to their practices and rulings, seam to agree rather well with educational loaders in regard to the school's obligation to society. They endeavor to keep the schools social and democratic. Bvening schools in 50 percent of the aygtems studied reflect the effort to provide some form of education for adults. Rulings relative to public relations indicate that 100 percent of these same cities feel that they wust belp to mold public opinion in regard to the schools. 
MANUAL FOR TGACHERS BASED UPON MTNUTES OF A BOARD OF BDUCATION

(Booklet $6^{\prime \prime} \times 9^{\prime \prime}$ in size is suggested, provided with occasional b.lank pages whoreon revisions may be made whon nocessury).

\section{Selection of the Material}

The subject matter content of every item included in the wanuel was either mentioned in many of the other handbooks wich were analyzed or was considered importent by the authoritieg in the field, and was embraced in a check list approved by ropresentative teachers of the system.

The idea was not to produce a model manual, but to write one based upon the minutes of a board of education and any rulings which that group or the Superintendent has issued. Only those principles and regulations were incorporated which the teachers had indicated as desirable for inclusion in a booklet.

\section{Source of the Material}

The polieies and rulings in this menusl vere derived from the winutes of the Louievilis Board of Bdueation, covering a period of twenty-four years from 1910, the dete of the act of the General Assembly of the Commonwealth of Kentucky, which ereated boards of education in eities of the first class. An anajysis of the Superintendent $" \mathrm{~g}$ bulletins and letters to the teachers was 21so made. Previous rulings, published in the 1916 handbook, 1sgued by the Board of Bducation, were incorporated when they wore found to be still in force,

This wethod of formulating rules is sanctioned by the autherities in the field. Daniel Eginton, supervisor in research of the 
Connecticut State Board of Bducation, says, "The ninutes of the board may profitably be studied as well as rules and regulations used in towns and cities having educational systems of recognised merit. Previous votes of the board should be studied and incorporated where desirablen. 1

The individual interview was used to discover what representative teachers want to know about the policies and rulings of their Board of Educatioh. The samplaing was made with great care to Include those teachers who were most able to deterwine whet types of information would be useful. Teachers who were rather nev in the syaten were usually chosen because they had not taught long enough to forget the items which they had with difficulty learned incidentally and which they thought ought to be in a handbook. Twenty-eight teachers with littlo local experience vere consulted from schools of various levels and neighborhoods. Faculty wembers from two senior high schools--a girls " and a boys ${ }^{\circ}-$ a trade school, a junior high, and selementary schools from both residentiel and industrial localitles were included. One school, in particular, veeteiegresented because, since it has a very effieient principal, a large proportion of its teachers are inexperlenced.

An explanatory letter from Dr. B. C. Blow, Assistant Superintendent in charge of Research of the Louisville City Schools, a aroused the interests of the teachers, who talked freely about the suggested items on a check list relative to a teacher's manual. They were asked to indicate any itemis not considered of Bducation". The American School Boerd Journal, March $1934, \mathrm{p} 10$. 
serviceable and to mention any essential ones not included in the check liat. The list must have been valid, since no teacher wanted to diacard an 1tem, and only one 1tem was added. Ten percent of the individuals interviewed suggested the addition of a code of othica--eithor the National Education Association 's code or Kentueky ${ }^{\circ} \mathrm{s}$,

The check 1ist was formulated after a study of Talbot ${ }^{2}{ }^{2}$ list, the litereture on the subject and manuals from eighteon cities. The writer started the list with the items which she felt she hergelf had needed to know when she had entered the aystem as an experienced teacher, but one unfamiliar with the local regulations. Her contacts with cadets in three types of day school, as well as in ovening and sumer school, had impressed upon her many topies, which, if reduced to writing, would gave both confusion and ombarrasament and would increase teaching efficlency.

Following are some of the teachers ${ }^{\prime}$ comments mede during the interviews: "I have always wanted to have a copy of our rating ocale so that I wight grade myself fraquently".

"Had a certain teacher I know possessed a copy of regulations, she never should heve written to the board in regard to a reduction of hor salary because she was tardy one day". "I could have avoided difficulty had I understood the board of education's attitude toward corporal punishnent. I certainly should not kave slapped thet boy".

"How embarrassed I was when I could not answer the question, How meny board membors has Louisville"? Bducational Research Bulletin, Vol. X, No. 10, 1931, p $258-260$. 
"If I had ownod a manual of regulations, my principal would not have found it necessary to tell me to remove a calendar which displayed some advertising matter". These and similar remarks reveal the fuct that teachers foel the need of a handbook whose Information answers such quastions as those just mentioned.

\section{Purpose of the Yanual}

The purpose of this manual is to help especially tho nowly appolited teachers to obtuin a broader understanding of their dutios and reaponsibilities, and to help them orientate themselves proxptly. It seeks to adjust the teacher easily to the material resources of the system and to the extfe-curricular and routine business life of the school. Its objective is also to make all all teachers feel that they are important factore in a great system and to incroase their realization that teaching wust always be upon a professional basis. It strives to interpret to the teachers their city's oducational system and to give them, in convenient form, the information regarding the school systers which they need to have for ready reference. 


\section{THE BOARD OF EDUCATION}

\section{1. 소는}

The Board of Ddueation of the Gity of Louisville, hereinafter referred to as "the Board".

\section{2. iㅣㄹibility of Members}

No person shall be eligible to the office of member of the Board who has not attained the age of thirty years and who is not an owner of real estato in the city, c citizen and a bone fide resident of Kentucky and of Loulsville for three years next precoding his election. No one is eligitle who holds or discharges any offiee, deputy-ship, or agency, under the eity, or any distriet or eounty, or under the state of Kentucky. No person shall be eligible to this office, who, at the time of his election, is directly or indirectly interested in any contract with the Board, or who holds any office of trust or agency of or draws a salary fros any corporation which holds any contract with the Board or whose father, son, brother, wife, daughter, or sister 1.8 employed as teacher or any other eapacity by such Board, or wo is, directIy or indirectly Interested in the sele to the Board of books, stationery, or other property. If he shall, efter election, become a candidate for any office or agency or for the romination thereto, the holding and discharging of which would have rondered hin ineligible before election, or if he should move out of the city, or if he shall do or incur anything which would make him ineligible for election, or if any of the relatives above specified be amployed by the Board, his office shall without further action, be vaeant and his succossor shall be chosen by the other members of the Board until the time of the next election. 
3. Number of Members

There shall be five members of the Boerd.

4. Compensation of Members

No compensation shall be paid to the members of the Board, but they shall be exempt fron jury duty and from service as election officers during their term of orfice.

5. Election of Members

The members of the Board shall be elected for the tern of four years by the qualified voters of the city. They shall be elected from the city at large by secret ballot. The non-partican ballot shall be on a sheet separate from all other bellots. 6. Vacanciog - How Filled

Any vaeancy in the Board, from whatever calse occurring, shall be temporaxily filled by the other members as soon as practicable after such vacaney occurs. The nember so chosen shall hold office until his sccessor is elected and quelified.

\section{Nootings}

R. Regular Keetings - The regular meetings of the Boerd vhall be held on the first Tuesday of each month at $8: 00 \mathrm{P}$. Mo

B. Special Meetinge - Speciel meotings of the Board may be called by the Prealdent whenever he may deem it necessary or wheriever he is requested to do so by two other members of the Board. No business shall be trensacted at a special weeting except that for which the weeting wes called and which was stated in the call. 


\section{Funetions of the Board}

It shall be the duty of the Board to appoint a Superintendent of Schools, a Business Direcotr, End Secretary and Treusurer, and such other officers, employoes, and sgents as it mey deem proper, provided that no such officer, amployee, or agent sholl be a member of the Board. It shall adopt policiess provide for the means of carrying tham out, and provide for the financing of adopted policies and meens.

\section{Orseniration}

A. officers

At Its first regular meetine after the first fay of January the Bourd shall reorgenize by selecting one of its members, President, and another Vice-preaident. The other officers shall be a Secretary and Treesurer, a Superintendent of Schools, and a Business Director.

B. Cormatt teอs

There shall be standing comittees, consisting of three meabers esch to be appointed annually by the President, as follows:

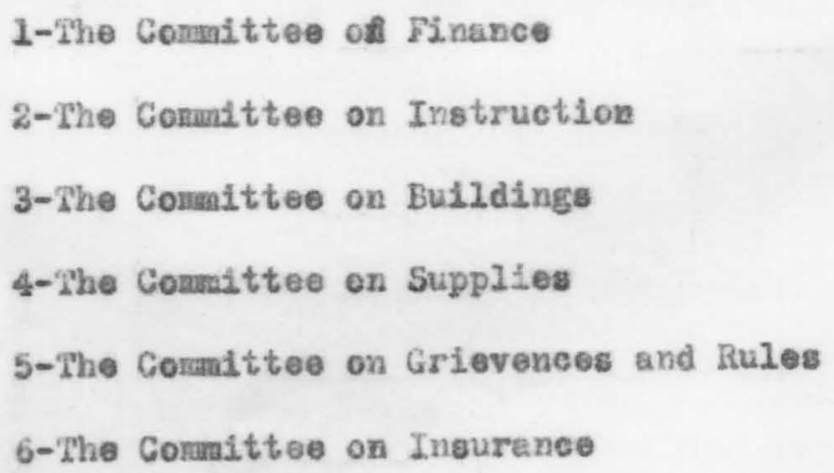

C. Secretary - Treasurer of the Board

The Secretary-'Ireasurer shell keep en aceurate journal of the Board's proceodings, receive a.13. funds belonging to the sehool district and pay out the sane on orders approved by the Board. 
D. Business Nanager of the Board

The Business Manager of the Board shall have genefal supervision of all school bulldings, their equipment, and repairs. He shall have oirect charge of a.11 buildinge employees. He shall be responaible for furnishing aupplies on all requisitions aade by the prineipals and supervisors.

\section{SUPSRINTANDENT OF SCHOOLS}

Under the general direction of the Board the Superintendent shall exereise a generel. supervision over all the schools and ahall see that its policies are faithfully observed in all departments. He has the following powers snd dutiess

A. He shall be the administrativo head of the school system, His functions are to formulate, for the consideration and action of the Board, policies and general rules of procedure; to put into effect such policies as the Board approves; and to formulate necessary directiong for the gukiteince of touchers.

B. He slall have a seat in the Bourd and the right to speak on 811 watters before the Board, but he cannot vote at the weetings.

C. He shall have power to suspend any teacher for cause deesed by him sufficlent, and the bosid shell take such action upon the restoration or renoval of the teacher es it may consider proper.

D. He ghall have power to close the schools or any department thereof temporarily; or grant temporery leave of absence from school to any teqcher when necessary; to make such 
other temporary arrangements reletive to the 8 chools as he way consider proper and report to the Board at its subsequent meeting.

F. He shall provide prineipals with blanks and forms necessary for the efficent and econowical handling of all books and supplies and also forms for keeping and submitting records.

F. Unless absent by the congent of the Board, he shall be present at his office at stated hours.

G. He ahall nominute, subject to the approval or rejection of the Board, all teachers. He shall make all assignments of teachers throughout the eity.

H. He shall perform such other duties in the interests of the schools.

\section{ASSISTANT SUPERINTENDUNTS}

There shall be four assistant superintendents as follows:

1. Assistant Superintendent of Research

2. Assistant Superintendent of Secondary School.

3. Aasistant Superintendent of Blementary Schools.

4. Assistant Superintendent of Practical Arts and Industrial Bducation.

They have authority over all matters pertaining to the various departments indicated in their respective titles.

\section{SUPERVISORS}

There shall be supervisors of kindergartens primary grades 1 to 3 intermediate grades 4 to 6 ; art; musie; health; and attendanee. The supervisors shall instruet all teachers, both in private and in teachers ${ }^{\circ}$ eetings, in regard to their special 
aubject. They shall be counselors and guidesito the teachere and shall ondeavor to work with and through the principals, maintaining cordial and sympathetie relationships.

\section{GENERAL POLICIES OF THE BOARD OF EDUCATION}

It is the policy of the Board of Education to give to the teachers such freedom as to onable them to exercise initiative in the use of sound principles and correct metnods in securing results and to permit them to develop their ow individual powers. The ultimate purpose is that all who are engaged in educational work may reach the highest plane in their own personal powers and may render the maximal service to the system.

The best service is not that which is prescribed and governed by rules and regulations, but it is that service which is given because of the joy of serving and because of pride in doing a professionel task well. All true proressional workers are their own best and severest critics, and, no matter how well they may be dolng their work, they are always earnestly and enthusiastically seeking to improve the quality of their service.

Between what the law requires as a minimum and what it is possible to do, there is a wide margin. Within this area, the successful teacher exercises initiative and works out new and better ways of teachling.

The underlying philosophy that determines the policles of the Board of Bducation is that idea that every child shall be given an opportuaity to live richly and happily as 8 child, that each one shall be given the chance to develop fully his individuality, and that he shall be brought to desire the better things of life, not only for himself, but for the group of which he is a part. The 
school is expected to onable the pupils to build up health, to value the fine art of living together, to learn eitizenship by practicing it in the school, to desire to keep on learning, to employ the higher uses of leisure, and, above ell, to develop fine eharacter. The neods of society determine the aims of educatioh, cousequently the school must become a laboratory for democracy, wherein oyery individual is at the same time a citizen, a worker, able to pull hile own load, and a distinct personelity. The achool's chief function is to enable the child to live a normally satisfactory life for himself and to contribute his full share toward social progress.

The school must consider the whole childs it must be interested in his mental as well as in his physical health, in his omotional as well as in his intellectual growth. The school must give the pupils sense of his power as an individual and must train hiv in self-critieisw, in initiative, and in adaptability. As a mamber of a democracy, the pupil must lekrn to think for hinsels but to act with others. He must be trained in cooperation, organization, and other social attitudes and ideals necessary for society's progress.

The testing program is an outgrowth of the principle that the sehool must consider each pupil individually, for this plan discovers the superior ehild and keops him from loafing and preventa the slow one from becoming discouraged; since the assignments way then be made situable for the individuel, and esch pupil may work to his limit. 
The guidance program depends upon the principle that society, being dynamic and not static, demands that the pupils be trained to fit into their proper niches, that they not become subject to fates Inposed upon them from the outøide, but that they help to shape their own careers. They should not be Indoctrinated but should be taught to develop their own opinions, which, oven when formed, are to be hold tentatively.

The board of edueation feels that few normel pupils should be allowed to fail in a grade and so be compelled to repeat the work. The repetition of a grade is not the remedy for poor work; the cure is greater stress on the fundamental principles of instruction, and more work upon these individual cases. Failure breeds more fallure and inferlority complexes. The only messure that can be reasonably applied to the work of any individual is the one which asks that, considering his ability, health, and home enviroment, he do the best he can.

The principles that one learns by doing and through satisfying experiences compel the achool to exphasize the value of pupil-controlled activities. Clubs and other school organizations are used as a means of broadening the horison, of stimulating new interests, and of promoting teamwork throughout the entire system. Numerous wotivated situations and sels-directed activities should be afforded for purposeful pupil participation.

The public school, supported by taxes from all, should be non-political and non-sectarlan; consequently all employess must be alert to keep out of the school a.1 political and sectarian matters. All forms of propaganda and advertising must also be excluded. 
Frow the principle that the pup1ls learn through purposeful participation in experiences, it follows that teachers must set a variety of pupil activities and must regulate the physical conditions of these activities. The temperature must be regular, the lighting suffieient, and the ventilation adequate. Order mast be maintained. Iquipment must be in its appointed place and be handled intelligently. Most important of all, the atmosphere aust be peaceful and joyous.

The teachers are expected to exercise their right as citizens but to keep political, religious, and personal propaganda out of the classroom.

\section{TBACHIRS}

\section{Appointment of Teachere}

Teachergl shall be appointed annually in June for the term of one school year. They shall be recommended for appointment by the Superintendent and approved by the Board of Education. 2. Basis of Selection

A11 teachers employed by the Board of Education muðt be at least eighteen years old and shall be lchosen with reference to educational, moral, and physieal fitness, and, after having been once employed, shall be subject to re-appointment during good bohavior and officient service.

\section{Physical Fitness}

No teacher shall be appointed or re-appointed who is deaf, consumptive, or affected with any contegious disesse. The supertendent way authorize a physical examination in any cese where he considers it necessary.

1 The term "Teacher" shall be construed to include both eexes. 


\section{Certification}

No person shall be eligible to appointment to any position as teacher who does not hold a Kentucky teacher's certificate of state-wide validity or a certificate of local validity issued before June, 1933.

\section{Appointment of Mormal School Graduates}

Normal graduates are ranked in two 1ists, namely? (1) teachers of prinary grades and (2) teachers of intermediate grades - In order of their general average; so that as each new class is graduated, the graduates will be ranked with the preceeding ones on the same basis, and all appointments to the elementary grades are made on the basis of these 1 ists and 1 in the order of the ranking. 6. Bducational Reguirenante

No teacher shall be employed in the elementary school tho has not had two years of acceptable training of college level above high achool graduation.

No teacher shell be employed in the junior and senior high school who dees not hold a bacealeureate degree from a standard sollege.

\section{Experience}

A teacher with a laster's degree frow a college way be appointed to a high school position without having had exp rience in the grades.

\section{Narried Women as Teachers}

No married woman may be appointed as a teacher in the public 8chools. The marriage of a woman after her appointment autonatieally constitutes a resignation of her position to take effect 
Iramediately. Any student of the Norwal school shall be automatically withdrawn upon her marriage. Those married women already in the service may be retained subject to re-appointment by the superintendent.

\section{Signing Contracts}

All teachers who shall be appointed or re-appointed are requirod to sign and return thoir contracts within twenty days after receiving them. Failure to do so vill be considered a declination.

\section{Dismisgal of Teachers}

Teachers or other exployees may, after two weeks ${ }^{\circ}$ notice, be dismissed by the Board of Education for wilfully violating any of the regulations of the schools, for not faithfully discharging their duties to the pupizs, for imorel character, or for any other sufficient ceuse.

\section{Promotions}

Promotions of teachers from one type of position to another shall be made on the besis of treining, experience, and merit.

\section{Change of Salary}

The salary of teachers may not be changed duxing the term for which they are elected, for they aro publie officisls, and no public official may have his salary changed during the term for which he has been elected.

\section{Absence}

No teacher way be allowed to be absent from school. without permission from the Superintendent except on a ccount of 111noss of self or death in the frmily. 
A. Dus to Death in Family

In case of death in the immediate family of an employee of the Board, three days ${ }^{\circ}$ absence may be granted without loss of pay.

B. Due to Illness of Self

When absent because of illness of self, teachers ohall be paid one-fourth of their salary unless tre absence is, longer than a school term.

C. During Quarantine

In a.1 cases of teachers' being quarantined on account of a contagious disoase, no deduction is wade from their salaries undess the absence is longex than a month. If the quarantine is in excess of a month, toachers will be pald for excess tine at the rate preactibed for illness of self.

D. Notifieation to Principel

Teachers should notify the principal of impending absence as goon a they are aware of the fact themgelves and should also signify in advance the date of thair roturn.

\section{Leave of Absence}

A. On Aecount of IIIness Formal Leve because of 211 health may be obteined for a semester with one-fourth of alary on presentation of a physician's certificate. This leave may be extended another semester without any gelary. 
B. For Study

Bducational leave for a s mester's or a year's work at a college may be obtained with no salary.

C. Reinstatment After Leave

When toachers desire reinstatement after a leave of absence, they should apply by letter to the Superintendent. The former position eannot be assured.

\section{Resignation}

Any teacher may resign, providod four weeks notice of such Intention 18 given to the Superintendent. A tescher who withdruws whout giving such notice may forfeit one wonth's pay or such part as the Board of Education may direct.

\section{Annuity Fund}

Bvery teacher pays into the annuity fund ten dollars annualiy for the first fifteen years of her teaching career and twenty dodlers oach year thereafter. This amount is deducted in equal amounts from the October and Fobruary checks. If a teacher withdrawe from service before retirement, one half the sum paid is returned without Interest.

17. Rotirement

Teachere are not retired at any specific age but whenever the superintendeat is convinced that they are no longer efficient. 18. Scale for Rating Teachors

$$
\text { (Rate teachers } \mathbf{1}, 2,3,4 \text {, or 5) }
$$

\section{The Classroom}

A. The Child

1. Interest

2. Participation

3. Experience of success

4. Growth 
B. The Work

1. Worthwhilenese

2. Ain apparent

3. Orgenization

4. Use and richness of illustrative material

5. Profitable expenditure of time

6. Proportion of teacher and pupil activity

7. Leading-on qualities

8. Check-up results

9. Habit of building on previous experiences

10. Conmand of Finglish

11. Alertness to the big objectives of education -
(a) Hor.th
(b) Command of fundamental processes
(c) worthy home wembership
(d) Worthy use of leisure
(e) Bthieal character
(f) Citizenship
(g) Vocation

2. The School

A. Attitude toward Sehool,

Professional and Comunity Obligations

1. Willingness

2. Cheerfulness

3. Untiring loyalty

B. Projects - School,

Comaunity, Pupil-Aetivity

1. Cooperation

2. Zeal

3. Initiative

4. Leadership

Adopted by the Board of Education through the Principals GIub, Jan. 1930. 


\section{Explanation of Rating}

The rating "I" should be given only to excellent teachers who do unusually superior work.

The teacher rated " 2 " is considered above the average.

The tas teacher is average.

The one with a rating of "sु" should be given stimulation and special help by the principal and supervisors. If there is no improvement after a year, such a teacher should not be re-enployed. The chief purpose of rating is the Improvement of teachers.

The principals are to rate the teachers each apring by this scale, whereupon a report of the ranking is sent to the Superintendent. The grade, however, may be changed by the principal any time during the year. The teachers have the privilege of discussing their grades with the principal, or they may have access to their ratings in the Superintendent's office. (Superintendent' 8 Bulletin, Jan., 1930).

\section{Recorded, Rating}

At least once each yoar the Superintendent shall file and keep as a permanent record the rating of each teacher as submitted by the prineipal.

Whenever a principal or supervisor is aware of any matter which might lower a teacher's rating, it become the duty of the former to give proupt notice to the teacher concerned, in order thet he may have an opportunity to correct the matter before it Lowers his grade.

\section{Observance of Rules and Regulations}

Teachers are required to familiarize themselves with polieles and segulation of the Board of Bducation, especially such as 
relate to their own duties and to the instruction and discipline of their own rooms, and shall be held responsible for their observance. They shall also observe and carry into effect all the supplementary directions of the Superintendent and of all others who direct their work.

22. Viaiting Schools

The Superintendent may grant permission to teachers to visit other schools, without loss of pay, one day a year, whenever, in his opinion, the best interests of the school will be advanced thereby. This should be done at a tine convenient to the principal, so that he may arrange the schedule in order to release the teacher. In such cases the visiting teachers shall, if requested, send to the Superintendent a written report of their observations. 23. Affillation with Bducatiohal Groups

Teachers are expected to become members of their local Parent-Teachers Association, the Loulsville Educational Associetion, the Difth District Association, and the Kentucky Bducational Association. Membership in the National Educational Association is cownendable.

24. Prolessional Attitude and Imorvenent

A. Since the education of youth is so largely dependent upon the efficiency and success of the teacher, it is expected that teachers shall devote all their time and energy while at school unreservediy to the preparation for and the prosecution of their work.

The success of any school system is determined in the elassroou at the point of contact between teacher and pupil. The 
point of contact between teacher and pppil. The establishment of happy, helpful relations between teacher and learner is the aupreme test of any achool adminiøtration.

B. Teachers are expected to improve themselves professionally through conferences, meetings, lectures, university courses, and suramer school work, which will give them greater skill in teachIng; however, they are warned not to undertake so much study for professional advancement that their elassroom efficlency w1II be Impaired - three semeater hours should be the limit of work taken during a school semester.

C. Every good teacher should read the state school journal and other educational wagazines, ag well as good professional books. 25. Houre of Duty.

A. Tardiness

Teachers are required to report themeelves to the principal and be present in their respective room fifteen minutes before the time for opening school in the morning. All tardy teachers shall be subjected to a deduction of onefourth of a day ${ }^{\circ}$ salary, except in cases of slekness, or such other reasons as may be approved by the Superintendent upon a written statement of the principal and teacher. B. Hour of Dismissal

Teschers should remain in the school buildings in the afternoon until such time as the last grade is dismissed, and not later then one hour after such dismisal, unless for some apeciel purpose, such as a weeting of the ParentTeacher Association. Teachers whose elasses are dismissed somewhat earlior than others should place themselves at the disposal of the principal and help in many ways to carry 
on the work of the school. The early leaving of a few teachers has a tendeney to weaken the worale of the school. All teachers should remain in the school butlding after the diamissal of classes long enough to give special encouragement or holp to any pupil in noed of either.

c. Seturday Korning Neetings

Teachers should hold themselves at the disposel of school officials on Saturday mornings for conference and assignsents, should the nocessity exise. They should attend all meetings after the regular school session to which they are called by the Superintendents or Supervisors.

D. Extra Curricular Aetivities

All teachers will undergtand that their duties are not confined to their elassrooms. They will be assigned from time to time various duties pertaining to playgrounds, Iuth rooms, assemblies, and other activities.

B. Attendance at Meetings

Teachers should attend all meetings to which they are called by the Superintendents or supervisors. F. Faeulty Meeting

The teachers should hold themselves in readiness Tuesday afternoone for a faculty moeting. Other short meetings may be called at the discretion of the principal.

26. Use and Gare of Course of Study

Teachers' prograve of instruction in the elassroom should be guided by the courses of study that have been provided for all 
subjects and grades. These bullotins should be carefully preserved and should be returned to the principel at the end of the school year.

\section{Pupil Accounting}

A. Records

The keeping of accurate and complete records is imperstive. Current records are necessery for the making of reports; while permanent ones are needed for reforence. Teachers shall keop daily a reciord of the attendance and punctuality of the pupils. The scheol attendance law stipulates that teachers be very accurate in daily records of attendance. It is importent that teachers preaerve records of the pupils" achlevements in order to give just marks at the end of each report peridd.

B. Pupils' Reports

Pupils" reports showing attendance and achievenents shall be issued on regular report forms at stated intervals as determined by the spperintendent. G. Report of Truancy and Absence

Teachers shall report promptly truants or suspected truants, if absent, and shall send a card to the howe upon the second day's absence of those pupils whose absence is unexplained.

D. Promotion of Supernormal Pupils

Teachers should notify the principel when, in their judgment, any pupil is capable of advancement; so that such a one may be examined and transforred, if found competent, to a higher grade. 
B. Requisitions for Supplies

Requisitions for books and supplies are prepared on rogular forma periodically under the direction of the principal.

28. U8e of Books and Equipment

A. Reading the Bible

The schools shall be opened deily by the reading of a portion of the Bible without coment. B. Wereter Text Books

No taxt book shall be used regularly in the schools unill approved by the Board of Education. C. Inventory

An accurate annual inventory of til equipment and supplies shall be aent through the principels to the business menager each spríng.

D. Property Responsibility

Teuchers shall take care that their respectivs rooms, a. we11 as their furniture, apparatus, supplenentery books, and other school property belonging to their rooms, be not defaced and danaged. They shall report any injury to the principal. Proper eare and economy should be exercised in the use of all supplies furnished by the Board of bduction.

\section{Regulations of Physical Gonditions of Room}

A. Heat

Teachers should maintain, as far as possible, an even Weltore temperature of 68 degrees or 70 degrees in their rooms. 


\section{B. Ventilation}

Teachers ahould give vigilant attention to the ventilation of their rooms. Bvery room not provided with forced ventilation should frequently be flushed with fresh air, and the best provision possible should be made for continuous ventilation.

\section{Lighting}

Although it is expected that teachers will make proper use of artifielal light on dark days, it is also expected that they wil exercise economy and not use electricity unnecessarilyt By raising window shades to within \& few inches of the top of windows, often artificial lighting may be be avoided. Lights should be turned off when the teacher leaves the room. Teachers should exercise care for the eyes of the pupils in regard to excessive light or glare.

\section{Fire Drilis}

Fire drills shall be held frequently and at irregular intervals. Bvery precaution must be used to allow free egress from the building, and one or more pupils must be instrueted to op $\mathrm{n}$, upen a given signal, all outside doors. When the specifled fire alare is given, all pupils shall form as determined by the teacher or principal and remain in position until ordered out of the building or sent back inte the rooss. One stroke of the gong will notify pupils to pass out of the building immediately in lines without waiting for wraps. The fire signals must be distinct from all others and must be used only for flre drill purposes. The gignals and drills must be as nearly uniform in all builèings as their construction will permit. As the building is emptied, the 
teachers should wee thet no pupils are left behind. Ordinerily the teachers should stand at the door to bo used, until their pupils have passed out of the door, then they should follow at the rear of the Iine.

Teachers and several pupils in every bullding should be teught the use of the fire extinguishers. 


\section{Attitude of Teachers Toward Principal}

The proper propessional relationship that should oxict between teaciers and principals is shown in the following list of requisites which was formulated by the Principals' Club and approved by the adainistratie stafrs

1. Ihtablishment of a working agreement as to the aims and objectives of the school, based on a conmonly sccepted philosephy of education.

2. Bstablishment of a feeling on the pert of the teachers that the principal is a professional leader to whom the teachers may turn for help and support.

3. Jistablishment of a feeling that the principal welcomes suggestions and joint action in determing the school policies and in carrying thom out.

4. Bstablishent of a feeling of matual friendship, cohfidouce, aympathy, and respect between the teecher and principal.

5. Bstablishment of a hearty cooperation betwesn all members of the school to facilitate the work of the whole school.

6. Appreciation by the prineipal of the ors of the teacher and by the teachers of the work of the principal.

7. Bstablishrent of a feeling that the principal may delegate to teachers authority with responsibility, and a feeling by taechers that the principal will support tham in their actions.

8. Isatablishment of a feeling that a teacher mey develop hor initiativ6, a long as her efforts do not conflict with the established aims of the school. 


\section{Teachers ${ }^{\circ}$ Relations to Pupils}

Teachers should consider the individual differences of pupils, should remember that education is for the whole child, and that it is a matter not so much of instruction as of guidance and growth through purposive activity.

\section{A. Health of Pupils}

Teachers are expected to maintain a careful daily oversight of the health of their pupils and should report immediately to the prineipal any situation that requires attontion. B. Supervision of Puplis Outside the Schoolrow

Teachers are expected to maintain a general supervision over the conduct of pupils, not only in the schoolrooms but also at Iunch time and on the way to and from school. Teachers should exert their influence to maintain proper bohavior among the pupils at all times and to prevent quarrels, rudeness, and bolsterous conduct. C. Diseipline

Teachers shall strive to administer such discipline as is exercised by a wise and judieious parent in his home, always firm and vigilant but, at the same time, kind, prudent, and sympathotic.

Corporal punishment should be rasorted to only after other means of discipline fail. This punishment can be administered only by a principal in his offlee or by a teacher in the presence of the principal in the office. The principal report to the Superintendent each case of corporal punishnent at the time it is inflicted or as soon thereafter as possible. 
In no case shall resort be nade to confinement in closet or wardrobe, or to dher eruel or unusual punishment as a mode of discipline. Puplis should not be required to any part of a text book, to write any worll or sentence a great number of times, or to perform any school task as a punishment.

\section{Subscriptions and Sales}

\section{A. Solieiting Funds from Pupils}

No collection of money, aubseription, or contribution for any purpose whatsoever shall be taken up in any school unless such action is authorized by the Superintendent.

B. Ticket Salez

There shall be no ticket sales in the schools except for gchool activities.

C. Sale of Candy, Tablets, ote.

Candy, tablots, books, otc., may not be sold to the pupils without the consent of the Superintendent.

D. Seasonal Gifts to Teachers

There shall be no collection of money for Christmas or or other seasonal gifts in any school, and there shall be no delivery of gifte at the school building.

Showers and parties of all kinds arranged by pupils in honor of tecchers are prohibited in school bulldings or dering achool hours.

Teschers shall not meke presents to their privicipals or other supervisory officers. 
Ih. Subseriptions frose Parents

Teachers must not solicit subscriptions from the parents of their pupils.

34. Tutoring

No teacher shall tutor for pay any pupil in his classes at any time within the school year, nor shall any teacher give private lessons for pay during the school yoar unless such action is sanetioned by the Bosid of Bducation.

35. Relations with the Fublie

A. Advertising liattor Displayed

All teachers shell decline to display or circulate any advertisenent of any kind whatsoever in the schoolroom. B. Agents and handbills

No person shall be perwitted to visit any school as agent of any entertainment of any kind, nor to distribute band-bills among the pupils on the school premises without peraission of the Superintendent.

C. Nanes Given

Teachers shall not furnish nor perralt to be copied from their rolls any lists of pupilo or other data for any purpose other than for requirements of the schools.

D.Propaganda

Outside organizations should not regard the schools as places for spreading progaganda. If they wish to send a opeakar into the schools, they should place their requests before the Superintendent. In order to keep propeganda and controversiel matters out of the classroov, teachers should examine carefully every issue of all leaflets, papers, etc. before placing it in the hands of pupils. 
B. Sectarian and Partisan Matters

Teachers should guard againet the introduction of ques= tions of a sectarian or partisan character.

F. Outside Speakers

No person shell be permitted to eddress the schools on any subject vithout the permission of the Superintendent. No speakers whose subjects are either secterian or controversial will be allowed in the school.

G. Interviews with Agents

Teachers are not to permit interviews in school time or at the school buildings with persons whose object is to have the tachers make purchases or investments. Any other forw of solicitaton is to be permitted only when permission therefor hes been given by the Superintendent. H. Interviews with Parents

Teachers shall not allow prolonged interviews ath parents or others to interrupt thelr classroom work. Parents or guardians aggrieved with the conduet of any teacher shall be entitled to private interviews with the principal or teacher, or both. Teachers should show interest, syrapethy, and courtesy in dealing with parents. The character and behavior of the teachers should be such as to inspire confidence on the part of the patrons.

I. Visits of Parents

Through the pupil, the parents should learn that at any time they will be welcome in the schoolroom. When parants are dissatisfied with the school in any respect, a visit is often ore of the best means of removing the dissatisfaction. 
J. Visiting Hemes

Tec.chers are oncouraged to visit, whenever feasible, the howes of their pupils in order to build up a better rapport between the home and school.

K. Intra and Inter-Sehool Activities

Intra-sehool activities should be encouraged as a substitute for Inter-school sctivities; inter-school sctivities should be cooperative rather than competitive.

L. Freedom from Partiasnship

No teachor shall electionesr or otherwise take part in any election during sehool hours or while on duty, under ponalty of suspension for the first offense and dismissal for the second offense at the discrotion of the Board of Bducetion.

36. General Regulations

A. Hemployment of Time

Teachers may not expley time outside of school hourse in any wanner which will interiers with their efficiency as teechers.

B. Disereetneas in Finaneial Affairs

Although the salery of no teacher or other eaployee of of the public schools shall be subject to attachment or garnishsent, the Board is of the opinion that it is contrary to the best interests of the schools that there should be in its employ anyone whe refuses to pay honest debts.

C. Teachers as Good Citizens

The Board expects teachers to build ug and promote a feeling of law end order in the comounity and of good will among 0.11 poople. 


\section{Channols of Communteation}

A. With the Board

All reports and comwunications to school officers or to the Board of Bducation should be sent through reguler official channels. The diagram of the organization of the school system page_._ll help teachers to understand, in general, the officiel channels of consunication.

All records and comnunieations of an official nature should come to the Superintendent through the principal. B. With Parents

AlI laportant comwunications addressed to parents are to be brought to the attention of the principal, who should cooperate with teachers in the peoper handling of eisunderstandings and other difficulties that arise with parents. C. With the Janitor

All requests involving the service of the janitor should be reported to the principal of the school who has the direction within the school building of all duties of jenltors: therefore the tescher is not expected to desl directly with the janltor for any kind of service to be rendered in her elavaroon. 


\section{PUPIIS}

\section{Admission of Pupils}

Children between the ages of four to $81 x$ may be admitted to the kindergarten.

\section{Vaccination Certifieate}

No child facy be newly admitted to the public schools unless he has a certificate of vaccination showing the date of successful vaceination.

\section{Ages of Pupils}

No pupil shell be continued in the public schools under the age of six years, except in the kindergarten. Noperson over twenty yesrs of age shall be permitted to attend school, unless he pays tuition in advence for each semester.

\section{Admission to Normal School}

Graduates of high sehool may be sdritted to the Normal School. When the enroliment of the school is large, entries will be taken from the high school graduates who have ranked in the highest third of their clasg.

\section{Courses Pursued}

Pupile shall be classified by the principal and shall pursue al1 studies prescribed for the grede, unless excused by the superintendent or principal for some adequate renson. Mere dislike or caprice does not justify the omission of a school subject.

6. Change of Residence

A pupil who changes $h i s$ residence during the school year may, If his parents so desire, complete the yeur in the school that he has been attending. 


\section{Transfer of Pupils}

Pupils may be transferred from one elementary school to another only upon the approval of the Superintendent.

High school students may not be transforred from one building to another except at the bezinning of a semester.

No pupil suspended or expelled from one school ghell be admitted to another without a special permit of the Superintendent. 8. Entering and Witering on School Premises

Pupils shall not enter the school grounda or buildings before the appointed time, nor remain efter school, without permisaion of the prineipal.

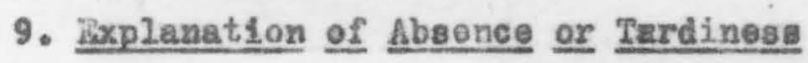

Pupils who are abeent or tardy for any reason must bring to the principal or teacher a written exeuse signed by the parent or guardian.

\section{Absance During Religious Holidays}

Absenee during days held sacred by parents will be exeused if the parents netify the school that their children were absent with their consent on aecount of the holiday.

\section{Excusing Pupils}

ฟo pupil after entering school in the morning shall leave the grounds without the consent of the principal, nor shall any pupil be dismissed except on the written consent of parent or guardian. All such requests, howevar, should be discouraged by the principal as much as possible. This rule does not conflict vith the teacher's or principal's duty to excuse pupils who are 


\section{Detaining Pupila}

No pupil shall be detained at any regular recess. Teachers way detain pupils (except those of the first and second grades) not exceeding thrity adnutes after the regular hour of dismiseing school, either for the purpose of displine or to make-up imperfect lessons, but no pupil shall be detained except for his own fault or nogisiok.

\section{Sending Pupils on Errands}

No pupil shell be sent on errands outside of school buildings, except by the principal and then only on mrgent school buginess, and an official record rust be kept of each case.

\section{Exclusion for Contagion}

Teachers asust be very watehful for symptoas of comunicable diseases. Pupils, excluded because of conmunicable disease or exposure to such a discase, may re-enter school only upon the authority of the Board of Health.

\section{Withdrewal of Pupils}

Pupils who withdrav prior to the close of the term shall take an examination before being promoted the following term unless their withdrawal was due to a contagious disesse.

16. Home Study

Pupils" interest in their atudies should carry over into their home life, but none, especially the elementary pupil, is expected to have to do eslcessive atudying in the evenings.

17. Accidents at School

The Bourd of Education is not legally responsible for injuries pupils receive at the schools and cannot pay damages, hospital, nor medical bills. 


\section{Use of Telephones}

Telephones shall be used strictly for business. The home should not call the pupil at school except in cases of emergency. Pupils must have the principal 's permission to use the telephone. 19. Butertainmente

The Board must be notifled regardine the proposed disposal of the proceeds from any enterteirment given by the pupils. 20. Simplict.ty of Glosing ixercisea

The closing exercises of school should be marked by simplicity as regards dress, flowers, etc.

\section{Non-Resident Tuition Fees}

Non-regident pupila must pay tuition evesy two months in advance. The Board of Education shall from time to time establish a ackle of tuition fees. The following rates are now in effect:

$\begin{array}{lc}\text { Nale Figh } & \$ 165.00 \\ \text { duPont Hanual Training High } & 165.00 \\ \text { Atherton High } & 165.00 \\ \text { Shamee High } & 165.00 \\ \text { Ahrens Trade } & 150.00 \\ \text { Central Colored High } & 105.00 \\ \text { A.ll Junior High Schools } & 115.00 \\ \text { Nornal } & 115.00 \\ \text { Colored Noral } & 135.00 \\ \text { Glamentary Schools } & 75.00 \\ \text { Open Air } & 67.50 \\ \text { Over-age pupils at High Schoolø } & 10.00 \text { per subject }\end{array}$


22. Credits Mrom Other Bigh Schools

Pupila way offer, as substitutes for subjects within a given curriculum in the high schools, credits made in other accredited schools, which courses are not offered in the curricula of the local schools but which are related. The number of such substitutions allowable is not to be in excess of six semester units; these substitutions to count toward gradustion from the high school wherein such substitutions are mide.

\section{3. geployment Certificate}

A permit to work may, when the issuing offlcer is convinced that the need is aufleient, be issued a youth who is under the age of sixteen but who has pased his fourteenth birthday and has completed the eighth grade, or to one who has passed his fifteenth birthday and has completed the seventh grade. 


\section{SUMAGR SCHOOLS AND GALISNDAR}

1. Summer schools for high school students shall be held for a term of six weoks. There shall be as for as is practical, a rotition of teachers from year to year, vo that the school system may derive the benefit from the assignoent of as large a number of efficient persons as possible in this branch of the service.

Students pursue two coursen at a fea of a $1 x$ doljars a couree.

\section{Vecations}

Vacations shall be in conformity with the scholagtic calender adopted before the beginning of each school year and shall include Thanksgiving and the following Friday, the days from Christmas to the day after New Year's Day, whe the twenty-second of February. 2. Observance of Special Days and Weeks

A. Days

\begin{tabular}{|c|c|}
\hline Columbus Day & Det. 12 \\
\hline Temperance Day & Det. 23 \\
\hline Arwigtice Day & Nov. 11 \\
\hline Kebtucky Day & Dec. 1 \\
\hline Lee 's Birthdky & $\operatorname{Jan} .1$ \\
\hline Lincoin s Buththday & Feb. 12 \\
\hline Waahington "s Birthday & 5eb. 22 \\
\hline Pan-Aneri.can Day & Apr. 24 \\
\hline Health Day & May 1 \\
\hline Arbor Day & Mey 5 \\
\hline World Goodwill Day & May 18 \\
\hline Menorial Day & May 3 \\
\hline
\end{tabular}


B. Wesḱs

Americun Education Woek

0ct. 3rd week

Book week

Nov. 3rd week

Kindness to AnIme 1s Week

Apr. 2nd week

Fire Prevention Week

Oct. 2nd week

Gonsunity Cheet Feek

Jan. 2nd week

Music Neok

May 2nd week

Better Speech Weak

Oct. lat weok

The days and weeks above and such others 2.8 may be designated by the superintendent are to be observed with appropriate exercises, and the pupila should be acquainted with the qualitiea of the great Americans honored and with the significance of the events observed. 


\section{YTSGBLIANEOUS}

\section{Use of Building}

Requests for the use of school buildings, accompanied by a atatement of the purpose of the meeting and the nature of the program, must be made in writine to the Business lanager of the Board of Bdueation.

No public school building may bo used by a religious group. The Board of Education grants the use of a building if proceeds Irom extertainements held there are for educational. purposes of a noin-soctarian naturs.

Cerd pertios sponsored by Parent Teacher Assoeiation cannot be held in the achool buildinga.

2. Flag Displayed

The Anerican flag shall be displayed from all school buildings during school hours, excegt in inclement weather.

\section{Smoking}

Swoking in school buildings and on school premises shall not be permitted. 
CHAPTIR VII

\section{CONCLUSIONS DRAWN MRON THE STUDY}

\section{GENARAL SUMACAR}

After a careful reading of the literature upon the subject of teachers" handbooks, a detailed analysis of such booklets, interviews with teachers themselves, and a painstaking study of the minutes of a board of education in order to ascertain its guiding principales, the following conclusione were drawn:

1. Carefully prepared handbooks are useful means of acquainting the teachers with the policies of their adrinistrators and are helpful in orientating ther as intoligent members of their school systan.

2. In content, manuals for tecchers should bo guiding principles rather than detailed rules.

3. In form, they should be sinple, with space for changes.

4. They should contain the board of education's policies toward the pupil, the teacher, and the public.

5. Bighty-nine percent of the boards want curricula and gethod to consider the individual child. Thoy foel that education moans the physical, mental, social, and emotional growth of of the pupils.

6. Seventy-two percent of the boards look upon teachers as indi= viduals and expedt them to exercise their initiative.

7. Boards of education feel that they must give the public the type of learning that it demands and yet must of ton help the public to desire a higher form of education. 
8. Teachers, as interviews with them indicated, want to know the executive and administrative organization of the scnool, and the rating scale, as well as the general duties required of them.

9. The handbooks studied do not measure up to meximum usefulness. Too much of their space is devoted to the use of school buildings and grounds, to the duties of the janitors, and to state laws and charters of the Boards of Education.

\section{Evaluetions of the "Wanued"}

(based chiefly on the Minutes of the locel Board of Iducation) The minutes of the local Board of Education show that, upon wany matters pertinent to teachers, the sald Board has not formuikted policies. For instance, it has no policy in regard to travezing done by teachers. Wany systems, at least in normal times, give bonuses for summer travel, but the local one does not even oignify that it approves of the teacher"s traveling.

The local Board is not abroast of ald progressive trends of oducation; for Instance, it bars controversial subjects from the classroom. It is not alone in thia respect because half of the handbooks have ruling similar to this one: "Any matter, whether printed, written, or oral, designed to influence pupils at to a matter to be moted upon by the people shall not be pernitted in the schools". 1

In analyzing wanuals and establishing criteria for rules, it 1s found that a ruie wust not be inconsistent with any authority higher than the board of education and must not conflict with the state code. A regulation is reasonable if its motive is the maintenance of the morale of echool administration. Although the 
rulings of the local Board of iducation are in harmony with the state code, sowe os them are not in accord with the educational practices considered best by authorities in the field of public school administration and superviaion. For example, the number of standing committees of the Board of iducatioh - six - Is not In agreement with the trend to have tho Board work as a comalttee of the whole. The fonaittee system fosters a divided, rather than a centralized or coordinated form of organization and comaittec policy tends to become Board policy, since the Board, as a whole, does not know about the raal work of each conaitteo ${ }^{2}$.

The organiation chart on $\mathrm{p}$ showg that Louisville has a aultiple type of organization wherein the superintendent is not made the chief executive officer of the board of education, Inasmuch as the secretary of the board and the business manager are not made responsible to the superintendent. Such an organisation could lead to all sorts of difficult conditions, should some of the executive officers happon not to possess an educational view poiat. Danger could easily recult in a situation, for instance, where the superintendent has no authority whatever over janitors. One cannot halp but warvel at ouch organisations thet have apparently been managed peaceably and rather efflciently. Specialists in public echool administration seem to be quits well agreed upon the advantages of a unit type of organization wherein one individual (the superinterdent) directs the administration of the whole organixation. According to Reeder, "Centralized control is considered to be, at least in all other flelds of endeavor, a first principio of efficient managenent. Try to imagine

2 Theisen, w. W., The Gity Superintendent and the Board of Education. Teachers College Contributions to Education, No. 84, 1917, p 35. 
a cozapany of soldiers having more than one captain or an industry having more than one superintendent: ${ }^{3}$ The practice of operating a school system with a number of independent executives tends to give certain positions prominence that beliss the purpose for which the public gchools are established ${ }^{4}$.

The statement in regard to physical fitness of the teacher is inadequate. where should be a positive, rather than a negative otanderd, Louisvilie, however, is not elone in failing to require a health certificate from teacherg, since only 49 percent of cities over 100,000 and but 9 percent in the sweller cities do require a phyoical oxamination ${ }^{5}$.

In refusing to employ married women the Loulsville Borrd of Bducation is in accord with the trend of practice in recent years, for 63 percent of the cities require wonen to resign when they warry 6 . The local Board agbees with the leaders in school administration in ito practice of omploying noa-residents and not limiting its selection of teachers to local applicants. 7

The ruling in regard to teschers" absence with one-fourth pay for a term has two dangers. In the first place, the pppils are Sygtes, Ginn i Co.s Chieagos IIl., 1929, p 17 .

4 Strayer, G. D., Report of the Survey of the Sehoola of Chicago, III., vol. I, 1932, $\mathrm{p} 34$.

5 "Adninistrative Practices Affecting Glessroom Teachers", Part I: The Selection and Appointment of Teachers", Research

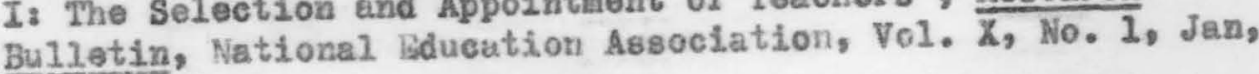
$1932, y 27$

6 Ibid, $\mathrm{p} 20$

7 Reecier, พ. G. The Fundanentels of Public Sehool Administration, Lacallien Co., New York City, $3930,870$. 
not protected Sron sick teachors who are unflt to do good work, while the long peried for paying one-fourth of the salary may become very costly to the Board. Cleveland8 grants her teachers full pay for ten days ${ }^{\circ}$ absence due to 11 lness 3 as does Heantramek, Michigan 9 , provided a coctor's cortificate is filed covering the absance after the third day. Cleveland Ellows the time to become cumulative to the amount of sixty days.

The proviaion in regard to retirement of teachers is inadequate. It $\Delta s$ dificult for a superintendent to know when teachers should be retired beceuse of incompetercy resulting from old age or from other causes. An objective measuring schome is nooded in determining when a teacher should be retired. The general prectice of most syatems to retire teachers at sixty or seventy years does not always result in justice to either the teacher or to the school ${ }^{10}$. The rule relative to the control of propaganda end exploitation is the schools accords with the present trend in all systems. "To hand over the child, still lacking in self-rellance and having little cheice as to what he shall do in school, to the unrestrieted influence of outside agencies would be the height of educational folly and the violation of a acred trust" ${ }^{21}$

St. Louls has aven more rigid rules than those of Louisvilla in regard to outside agents in the achools, advertising matter, and the giving of pupils names to commercial orgenizations. 12

9 The Public School Code of Flantramck, Hich, p 206

Redder, W. G., The Rundementals of Fubjic School Adwinistretion, Vacmiliex C0.8 New York, $1930, \mathrm{P} 154$ "Report of the Comitteo on Fropagande in the Schools", National Dducation Association, 1929, p 5.

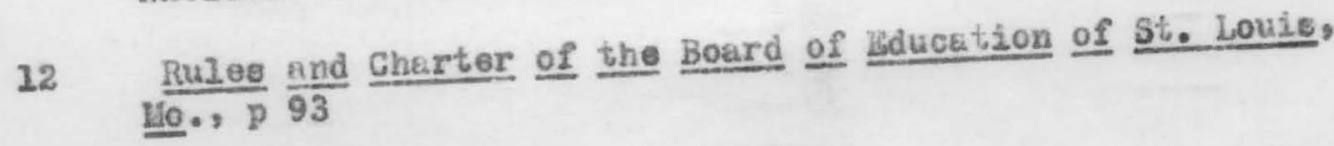


The manual for Loulsville teachers should have written into it something more explicit in regard to the school's relation wh the public, for the teachers have their part to play in interpreting the school to the public. "If a public school were aufficiently endowed that it need not dopend on the public for I1nancial support, it still could not function properly without the good will of its constituency"13.

It may be sefd hare that the local board, as well as some of the others, has auffered in its continuity fron death and resignation. It requires some time for a newly elected member to become intelligently acquainted with his responsibilities and with the with the best prectices in school administration ${ }^{14}$. Noreover, practice is always yoars behind philosophy.

However, in the light of previous studies, edueational administration and philosophy, and the specific analysis of other manuals, the rulings of thelocal board are not adequate for the teachers' neads. The check list approved by local teachers con= tains many items that neod to be written into the "manuel" compiled frow the Bosrd's policies. No salary schedule is included because the present one, which is not enforceds is being revised. On aome topics, probably because of the present economic poriod, the Boerd of Education has wisely refrained fron reducing certain policies to miting. Its attitude may sometimes be sensed from what it does not say as well as from what it does express.

13 Kent, R. A., "The School and the Social Febric", Flementary School Journal, Vo. 32, No. 10, June 1932, p T65.

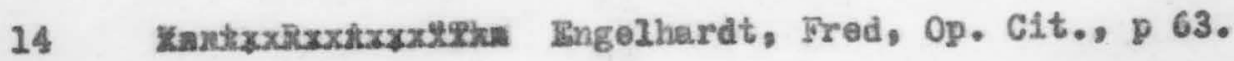


If certain topics included seem too trivial for inclusion in a handbook, it muat be ramembered that they are designed especially for beginning teachers and for those who enter the local service from sone other eity. Their inclusion depends, not upon theis agrearnt with good administrative practice, but upon the fact that they are the board 's regulations and, esch, need to be understood by the teachers.

\section{LIMTAITONS OF THE SIUDY}

The existing manuals, becauss of their need of revision, often do not contain the actual presentday practices of the boards of education. Only twenty-six percent of those studied bear a date as late as 1930; whilo one is twelve years old. In order that the manuals of trade and industry may be kept usable, they are ugually revised every two or three years. Bducational practices have undergone decided changes recently; so that many of the manuals do not now reveal the policies of the board of edueation, and it is not possible to learn their guiding principles frow their booklets of rules and rojulations.

\section{RESULTS OF TEE STUDY}

From interviows with teachers, one may conclude that there is a definite need for toachers $f$ handbooks, becauss the Board of Bducation's policies chart the course with the schools will take, and those polieles should be rellected in the printed regulations of the board.

The check list, included in this study, should be of some value as a guide in organizing manuls for teachers. 


\section{USE OF MATERIALS}

The waterials of this investigetion, that is, the analyses of bandbooks, the criteria set up for them, and the data in the incomplete wanual for Louigville teachers should be of sove value in providing an objective basis for the organistion of new handbooks or the revision of old ones.

The check list approved by local teachers wight help the Bosad of Bducation to realize that teachers want to understand the Board's attitudes on meny watters in regerd to which, from their absence in the winutss, one would have to conclude that the Board has not yot formulated polieies.

\section{FURTHER SIUDY}

The adequacy of a mamul based upon the check list evolved by the writer could be tested by having teachers who had used that wanual indicate any portions which they had found unneceseary, as well as those iters which they would like to have adeded to the ones already in the handbook. This suggests another study. 


\section{BIBLICGRAPHY}

\section{Books}

1. Almack, John C. and Long, Albert R., The Beginning Teacher, Houghton, Wifficin Co., 1928.

2. Alwack, John C. and Long, Albert R., Problemg of the Teaching Profession, Houghton, Mitrin Co., 1925.

3. Anderson, W. N., A Manuel for School Officers, The Centwry Co., 1925.

4. Bode, B. H., Modern Educationel Theories, Macmillan Co., 1928.

5. Chapman and Gourts. Principles of Education, Macmillan Cod, 1929.

6. Cubberløy, B. Lo, The Principal and His School, Houghton Miffin Co.,

7. Cubberley, E. L., Publie School Adminjistration, Houghton Mifflin, 1929

8. Dewey, John, The School and Sociaty, University of Chicago Press, Revised idition, 1930.

9. Dewey, John, Democracy and Education, Hacmillan Co., 1916.

10. Ingelnardt, N. Lo and Engelhardt, Fred, Public School Business Administration, Bureau of Publications, Teachers Collego, Columbia University, 1924.

11. Bngelhardt, Fred, Fublic Gchool Organization and Administration, Ginn : Co., 1931.

12. Haxt, J. Ko, A Social Internretation of Education, Henry Holt, 1929.

13. Kilpatrick, W. H., Bducation for a Ghanging Civilization, Macmillan, 1929 .

14. Kilpatrick, *. H. Source Book in the Philosephy of Educetion, Hacmililan Co., 1928.

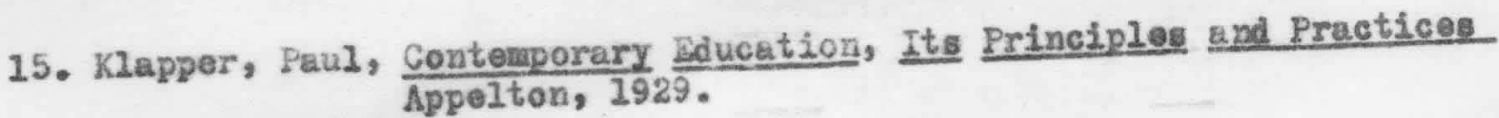
16.Lewis, Brwin Fe, Pereonal Problomg of the 'Teaching Starf, Century Co., 1925 . 
17. Lindsay, F. T., Problens in School Adrinistration, Mecnillan Co,,1928.

18. Martin, E. D., The Neaning of a Liberal Education, Norton Co., 1926.

19. Mendenhall, Bdgar, The City School Board Yember and His Task, collego Inn Bookgtore, PItroburg, Kan., 1929.

20. Horriton, Henry C., The Pructice of Teaching in the Secondary School, Chape 2 "objectives of Syetematic Teaching", University of Chieago Press, 1926.

21. Oppenheimer, Julius J., The Visiting Teacher Novement, Public Eduection Association of the City of New York, 1924

22. Pearson, Franeis B., The Tescher, Charles Seribner, 1 12.

23. Reeder, Fard G., The Busliness Adrainistration of a School Systern, Ginn \& Co., 1929.

24. Reeder, ward G., The Tundumentals of Public Sehool Administration, Becrijizan Go., 1930 .

25. Robinsox, James H., The Humenizing of Knovledge, Harpers, 2929.

26. Rug8 and Shumaker, The Child Gentered School, World Book Co., 1928.

27. Russell, Bortrand, Bduestion and the Good Iife. Boni and Liveright,

28. Srith, B. J.s Bducation Moves Ahead. Little Brown \& Co., 1926.

29. Strayer, G. D., Sone Problems $\frac{\text { in }}{\text { Book City }} \frac{\text { School }}{2926 \text {, Administretion, world }}$

30. Strebel, R. F., and Morehaed, G. C., The Nature and $\frac{\text { Meaning of }}{\text { Teaching, MeGraw-HIII Book Co.? } 1929 .}$

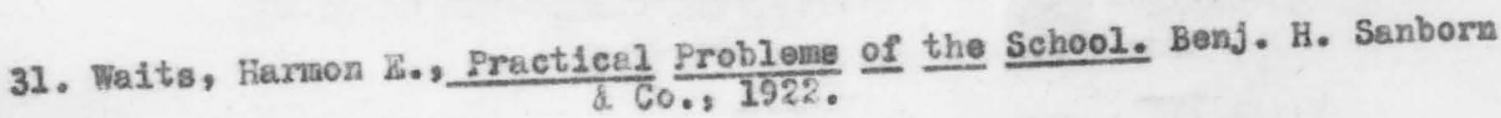

32. Washburne and Stearrs, Botter Schools, John Duy Go., 1928. 


\section{BIBLIOGRAPHY}

\section{Builet1ns, etc.}

1. Carrothers, George E. Physical Bfficiency of Teachers, Teachers college Contributions to Education, No. 255. Bureau of Fublications, Teachers College, Columbia University, 1924.

2. "The Duties of Blementary School Principals according to the Rules of Ninety-Five Cities", Seventh Yearbook, Bulletin 7; April 1928, Department of Elementary School Principels, National Mducation Assoeiation, Washington, D. C.

3. Eginton, Daniel P., "Rules and Regulations of the Board of Bducation", Americen School Board Journsl, March 1914.

4. Heer, A. L., "A Neglected Principal of Organization in the Administration of Our Public Schools", Bducationel Rosearch Bulletin 6i. Narch 2, 1927, Ohio State University, Colloge of Eciucetion, Columbus, Ohio.

5. Hubbard, Frank W., "Do School Systens Naed a Principals" Handbook", Eloventary School Journel 29 ipril, 1929.

6. Kent, R. A., "The School and the Social Frabrie", Elomentary School dournel, Vol. 32, No. 10, עuae 1932.

7. Knight, F. B., Qualities Related to Successful Teaching, Teachers Collego Contributions to Bducation, Ho. 120, Bureau of Fublications, Teacher College, Colugibia iniversity, 1922.

8. Helby, Brnest 0., "Rules, Regulations, and Written Instruetions as Adminiatrativo Controls", Amorican School Board Journal 74; May 1927.

9. Worehert, Grover Gleveland, The Legel Stutus of Gity School Boards, Contritutions to Edueation, No. 270, Bureau of sublications, Teachers Collogə, Columbia University, Now York, 1927.

10. Morrison, \&. Gayce, "The Value of Carefully Defined Rules and Regulativa Govarning the Works of the School Beard and the Superintendent", American School Board journal 72, Fobruary, 1926.

12. National Bducation Associbtion. Adnintatrative Fractices Affecting Clasaroom peachors, Researoh Bulletin, Vol. 10;

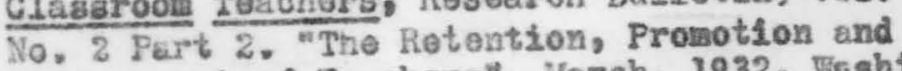
Improvement of Teachers", March, 1932, Wishington, D. C. 
12. National Education Association. Adminiatrative Practices Affecting Classroom Toachers, Research Bulletin, Vol. 10 No. 2 Part L. "The Secloction and Appointment of Teachers", Jan., 1932. Washington, D. C.

13. National Education Association. Circular No. 4, Karch 1930, Department of Superintendence and Regerch Division, Washington, D. C.

16. National Bducation Association, Facta on State Bducational Needs Research Bulletin, Vol. 1. No. 1. Jan. 1932.

15. National Rducstion Association, Facts on Fublic School for American Anericsn Education Weak. Research Bulietin, Vo. 2, No. 4, Sept. 1924, Washington, D. C.

16. Nationel Gducation Association. The School Board Lamber, Research Bullotin, Vol. XI, No I, Janusiry, 1933. Fashington, D. C.

17. Oleen, Fins G., The Work of Boards of Bducation, Contributions to Education, Ho. 213, Bureau of Publications, Teschers College, Columbia University.

28. TaIbot, George D., The Content of Teachers" Handbooks, Bducational Research Bulietin Vol. 10, No. 10: (May 13, 1931) The onie state Univeraity, College of Taveation, Columbus, Ohs.o.

19. "Texchers and Public" 프래 Yearbook, Department of Classroom Terchers. Netionel Bucetionel Arsociation, Wlashington, D. C., 1929.

20. Theisen, w1Jjiam W., The City Superintendent and the Board of Educst2on, Contributions to Education, No. Be, Tetchors Colloge, Columbis Univorsity, New York City, 19.17. 
The following letter and check list of items auggested for inclusion in a handbook for teachers were submitted to teachers who were asked to Indicate any 1tems not considered neceasary or to add any aseritial ones not mentioned in the cheek list. 


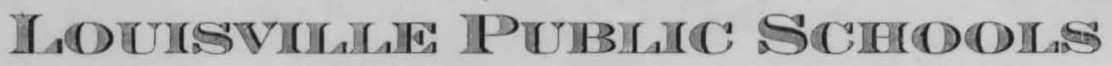 \\ BUREAU OF RESEARCH \\ ADMINISTRATION BUILDING \\ LOUISVILLE, KENTUCKY}

May 19,1932

Mr. W. S. Milburn, Principal

Louisville Male High School

Brook and Breckinridge Streets

Louisville, Kentucky

My dear Mr. Milburn:

For some time there has been a real need for a booklet or circular giving the rules and regulations which govern the working of our school system. It is hoped that when times get better we shall be able to publish such a booklet.

With this idea in mind, I am asking Miss Corwin to interview several principals and some of the teachers in the ir schools so as to determine just what types of information would be most interesting and useful to them.

I hope you will find time to go over Miss Corwin's check list with her and also direct her to several of the teachers in your school who might cooperate in supplying this information. With your aid I believe we can make the booklet decidedly worthwhile.

Very truly yours,

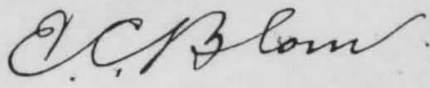

E. C. BLOM

Assistant Superintendent in

Charge of Research

$\mathrm{ECB}: \mathrm{DM}$ 
check Iist for Subiect Matter eintent of Manual for Teachere

Please cross out items you may consider unnecessary and add any others that you think should be included in teacher ${ }^{\circ}$ handbook. Administrative Organisation

Membersh1p of the Board

Flection-length of term-manner of election

Gompensation

Functions

officers

Comaittees

Schedule of meetjings

Vacancies-how f11led

Superintendent of Schools - Functions

Assistant Superintondents

Special Departments of the System

Headth

Attendance

Svening Glasses

Sumpev School

Continuation Classes

Grsph, showing executive starl organixation

Teachers

Appointment

Time

Length of tere 


\section{Certification}

Rducatiohal Requirements

Phyaical requirements

Tenure

$$
\begin{aligned}
& \text { Regulations regarding discharge } \\
& \text { Regulations regarding marriage } \\
& \text { Regulations regarding transfers } \\
& \text { Arranging for substitutes }
\end{aligned}
$$

Selarios

Sehedulo

Deduetions for pensions

Deduetions for absence duv to death in femily

Death in femily

Sickness

Quarantine

Other causes

Professional Growth

Plan of rating teschere

Profossionel reading expected of teachers Membership in professionel orgenisations

Attendance at teachers " meetings Attendance at sumber school, afternoon classes, etc. Vigiting other schools

Dutios

\section{Hanaging room}

Physiezl conditions

baterials and equipment

Instruction

Discipline ard eorporal punishment 


\section{Keepling of records \\ Dally reports \\ Wunthly reports \\ Annuel reports \\ Reports to parenta}

Relations with Fublic

Interviews with parents snd petrons

Visiting pupid's homes

Disereetness in I"inencial contacts

School Calendar (no definite dates because reviaion would be necessary too oftan)

Eolidaye

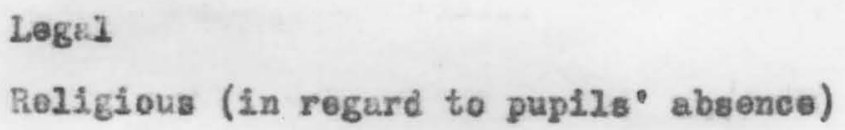

Legu 1

Religious (in regard to pupils ${ }^{\circ}$ absence)

School Vacations

Dates report cards are issued

Datøs annuel reguisitions are dua

Textbooks and other Equipment

Inventory of equipront

Rules regerding the securing of now materials

Books givon to indigents

Gansral Regulations Governing School and Glassroom

Organization and Adniniatration

Fire drills and firo-slarm

Mag displey and salute

Reading of the Bible

Length uf school day

Raising funds by salo of candy, etc. 
Collecting funda from pupils

Accopting gifts from pupils

Agents and solicitors in the building

Regulations governing tutoring

Regulations concerning teachers and janitors

Pupils

Home otudy requirenents

Detention sfter school hours

Use of school telphonas

Smoking upon school premises

Røgulations ragerding withdrawz before the close of the school term

Regulstions rogerding simplicity at Cormencements. 